\title{
Standard methods for fungal brood disease research
}

\section{Annette Bruun Jensen, Kathrine Aronstein, José Manuel Flores, Svjetlana Vojvodic, María Alejandra Palacio \& Marla Spivak}

To cite this article: Annette Bruun Jensen, Kathrine Aronstein, José Manuel Flores, Svjetlana Vojvodic, María Alejandra Palacio \& Marla Spivak (2013) Standard methods for fungal brood disease research, Journal of Apicultural Research, 52:1, 1-20, DOI: 10.3896/IBRA.1.52.1.13

To link to this article: https://doi.org/10.3896/IBRA.1.52.1.13

Published online: 02 Apr 2015.

Submit your article to this journal $₫$

Џلll Article views: 439

Citing articles: 32 View citing articles $\square$ 


\title{
Standard methods for fungal brood disease research
}

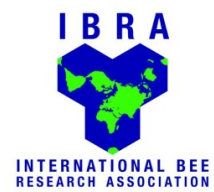

\author{
Annette Bruun Jensen ${ }^{1 *}$, Kathrine Aronstein ${ }^{2}$, José Manuel Flores ${ }^{3}$, Svjetlana Vojvodic ${ }^{4}$, María \\ Alejandra Palacio ${ }^{5}$ and Marla Spivak ${ }^{6}$
}

${ }^{1}$ Department of Plant and Environmental Sciences, University of Copenhagen, Thorvaldsensvej 40, 1817 Frederiksberg C, Denmark. ${ }^{2}$ Honey Bee Research Unit, USDA-ARS, 2413 E. Hwy. 83, Weslaco, TX 78596, USA.

${ }^{3}$ Department of Zoology, University of Córdoba, Campus Universitario de Rabanales (Ed. C-1), 14071, Córdoba, Spain.

${ }^{4}$ Center for Insect Science, University of Arizona, 1041 E. Lowell Street, PO Box 210106, Tucson, AZ 85721-0106, USA.

${ }^{5}$ Unidad Integrada INTA - Facultad de Ciencias Ags, Universidad Nacional de Mar del Plata, CC 276,7600 Balcarce, Argentina.

${ }^{6}$ Department of Entomology, University of Minnesota, St. Paul, Minnesota 55108, USA.

Received 1 May 2012, accepted subject to revision 17 July 2012, accepted for publication 12 September 2012.

*Corresponding author: Email: abj@life.ku.dk

\section{Summary}

Chalkbrood and stonebrood are two fungal diseases associated with honey bee brood. Chalkbrood, caused by Ascosphaera apis, is a common and widespread disease that can result in severe reduction of emerging worker bees and thus overall colony productivity. Stonebrood is caused by Aspergillus spp. that are rarely observed, so the impact on colony health is not very well understood. A major concern with the presence of Aspergillus in honey bees is the production of airborne conidia, which can lead to allergic bronchopulmonary aspergillosis, pulmonary aspergilloma, or even invasive aspergillosis in lung tissues upon inhalation by humans. In the current chapter we describe the honey bee disease symptoms of these fungal pathogens. In addition, we provide research methodologies and protocols for isolating and culturing, in vivo and in vitro assays that are commonly used to study these host pathogen interactions. We give guidelines on the preferred methods used in current research and the application of molecular techniques. We have added photographs, drawings and illustrations to assist bee-extension personnel and bee scientists in the control of these two diseases.

\section{Métodos estándar para la investigación de enfermedades}

\section{fúngicas de la cría}

\section{Resumen}

La ascosferiosis (o cría yesificada) y cría de piedra son dos enfermedades fúngicas asociadas con la cría de la abeja melífera. La ascosferiosis, causada por el hongo Ascosphaera apis, es una enfermedad común de amplia distribución que puede resultar en una severa disminución en el número de obreras emergentes y por lo tanto afecta la productividad de la colonia. La cría de piedra es causada por Aspergillus spp. los cuales son raramente observados y su impacto en la salud de la colonia no está esclarecido. El mayor problema con la presencia de Aspergillus en abejas es la producción de conidios aéreos, que pueden llevar a aspergillosis broncopulmonares alérgicas, aspergilomas pulmonares o aun aspergilosis invasivas en tejidos pulmonares en humanos luego de inhalarlos. En este capítulo describimos los síntomas de las enfermedades producidas por estos patógenos fúngicos. Además proveemos metodologías de investigación y protocolos para su aislamiento y cultivo, ensayos in vivo e in vitro que son comúnmente usados para estudiar las interacciones de estos patógenos con su hospedero. Damos una guía sobre los métodos preferidos utilizados en la investigación actual y la aplicación de técnicas de moleculares. Hemos añadido fotografías, dibujos e ilustraciones para ayudar al personal. 


\section{幼虫真菌病研究的标准方法}

白严病和曲霉病是蜜蜂幼虫相关的真菌病, 白严病由蜜蜂球囊菌Ascosphaera apis引起, 分布较广, 可造成工蜂羽化数量和蜂群生产力的急剧下

降。蜜蜂曲霉病由Aspergillus spp. 引起, 由于较少观察到, 所以其对蜂群健康状况的影响研究的不够深入。蜜蜂中Aspergillus引起之所以引起关

注, 是因为风媒分生狍子, 这种孢子可通过吸入引起人肺组织的多种疾病, 如过敏性支气管曲菌病, 肺曲菌球病, 甚至侵袭性曲霉病。本章我们 描述了这些真菌病原体的在蜂群中的疾病症状。此外, 还提供了开展寄主 / 病原体相互作用研究中常用的病原菌分离及培养技术、体内和体外测 定技术。并给出了最新研究中用到的首选方法以及分子技术应用方面的指导方针。增加了照片、插图和注释以帮助推广人员和研究者控制这两种 疾病。

Keywords: Ascosphaera, Ascosphaerales, Aspergillus, chalkbrood, diagnostics, methods, recommendations, stonebrood, COLOSS, BEEBOOK, honey bee

\section{Introduction}

Insect pathogenic fungi can be found throughout the fungal kingdom (Humber, 2008), all being capable of invading their hosts and overcoming their immune systems. Two fungal genera (Ascosphaera and Aspergillus) are known to infect honey bee brood, causing chalkbrood and stonebrood diseases. Both are ascomycetes within the Eurotiomycetes. The fungus causing chalkbrood in honey bees has a narrow host range and a unique infection route, it relies solely on sexual reproduction and has many host-specific adaptations. Therefore many methods known from common insect pathogenic fungi are not easily adopted to study chalkbrood.

In contrast, the fungi causing stonebrood are facultative pathogens with a broad host range, they produce asexual conidia and their infection biology resemble many well-known insect pathogenic fungi, like Beauveria and Metarhizium; so several standard insect pathological methods can be directly transferred to this system. In the current chapter, we compile, discuss and provide detailed protocols for various methods to assist beekeepers and bee scientists entering this area of research.

In addition to fungal pathogens causing chalkbrood and stonebrood, two species of microsporidia, Nosema apis and Nosema ceranae, are known to infect adult honey bees. Although recently suggested to be fungi at the very base of the fungal tree (James et al., 2006), these intracellular pathogens have a very different biology and are considered in a separate paper in the BEEBOOK (Fries et al., 2013).

\section{Chalkbrood}

\section{1. introduction}

Chalkbrood, the most common fungal bee brood disease, is caused primarily by the fungus Ascosphaera apis (Maassen ex Claussen) Olive and Spiltoir (Spiltoir, 1955). It was recognized in the honey bee in the early 20th Century (Maassen, 1913). The field diagnosis of chalkbrood is based on visual detection of diseased, mummified brood, commonly known as "chalkbrood mummies". Chalkbrood can reduce colony productivity by lowering the number of newly emerged bees, and in some cases may lead to colony losses. The disease is found infecting honey bee brood in most regions of the world, including warm and dry climates. Clinical symptoms of chalkbrood often appear for only a short time, typically under cold and damp weather conditions (Aronstein and Murray, 2010).

The genus Ascosphaera spp. comprises species that are adapted to eusocial and solitary bees and their habitats. Some of the species are saprophytic, growing on nest materials, such as stored food, faecal matter, and nest debris; others have evolved as opportunistic and / or obligate bee pathogens (Bissett, 1988). In honey bees Ascosphaera major and Arrhenosphaera cranae (both belonging to Ascospheraceae) have been reported only a few times from chalkbrood infected colonies, but Koch's Postulates have never been demonstrated for them, so they might be secondary invaders.

Ascosphaera apis primarily infects honey bee brood by entering the host through the gut lining. In an infected larva, hyphae penetrate the gut wall, and mycelium develops inside the body cavity. After a few days, mycelium breaks out of the posterior end of the larva leaving the head unaffected (Maurizio, 1934). Fruiting bodies with the new ascospores are formed on aerial hyphae outside the dead larvae. The ascospores are a result of sexual reproduction of fungal mycelia with the opposite sex, unlike most other insect pathogenic fungi where asexually conidia are the infective units, as e.g. seen in Aspergillus. Ascospores of $A$. apis (hereafter referred to as spores) are believed to be adapted to the harsh gut environment of the host. Ascosphaera apis infect the host larvae if ingested, unlike other insect pathogenic fungi which mainly infect through the external cuticle. Spores of $A$. apis can stay dormant and viable for years, but upon exposure to $\mathrm{CO}_{2}$ the spores becomes activated, resulting in spore swelling and subsequently germ tube formation that extends to form hyphae (Bamford and Heath, 1989). Presumably, $\mathrm{CO}_{2}$ produced by the larval tissues accumulates in the closed hindgut of the larvae aiding in spore germination (Heath and Gaze, 1987). However additional factors that may be involved in spore germination within the host still remain to be discovered. In addition, it has been shown that chilling of the brood below the optimal rearing temperature 
increases the number of diseased larvae (Vojvodic et al., 2011a; Flores et al., 1996a). All these specific adaptations have to be taken into account when working with $A$. apis, and specific protocols have been developed.

\subsection{Diagnostics and qualitative detection}

\subsubsection{Morphological description}

\subsubsection{Macroscopic diagnosis}

The typical symptoms observed in a colony affected by chalkbrood are irregular wax cappings over the brood and uncapped cells scattered over the brood frames (Fig. 1). The cell capping may also have small holes or appear slightly flattened. Chalkbrood mummies can often be seen in the combs, at the hive entrance or found on the bottom board (Fig. 2). Observation of combs may reveal different stages of the disease; fresh larval cadavers covered with white cotton-like mycelium and desiccated mummies that appear as white, dark or a combination of white and dark solid clumps. White desiccated mummies look like small pieces of chalk giving rise to the name of the disease and dark mummies are coloured by fungal fruiting bodies.

Diagnosis in the field is generally based on the presences of chalkbrood mummies (as described above). Following field diagnosis, a microscopic examination is usually required to confirm the presence of spore cysts in the samples using the microscope slide smear technique. The spores can be mounted on a microscope slide with a drop of distilled water and observed at 100-400 x magnification.

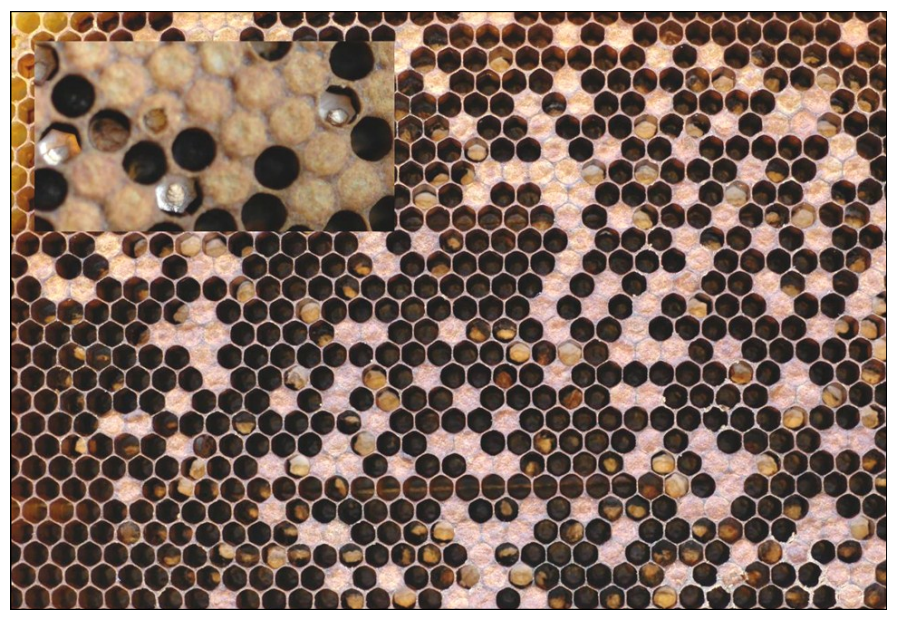

Fig. 1. A brood frame from a honey bee colony with clinical symptoms of chalkbrood and a close up insert of fresh mummies. In many cells chalkbrood mummies have been partly removed by the worker bees. Photo: F Padilla, J M Flores and A B Jensen

\subsubsection{Microscopic diagnosis}

Ascosphaera apis has septate hyphae (2.5 - $8.0 \mu \mathrm{m}$ in diameter) which show pronounced dichotomous branching (Spiltoir, 1955; Skou,

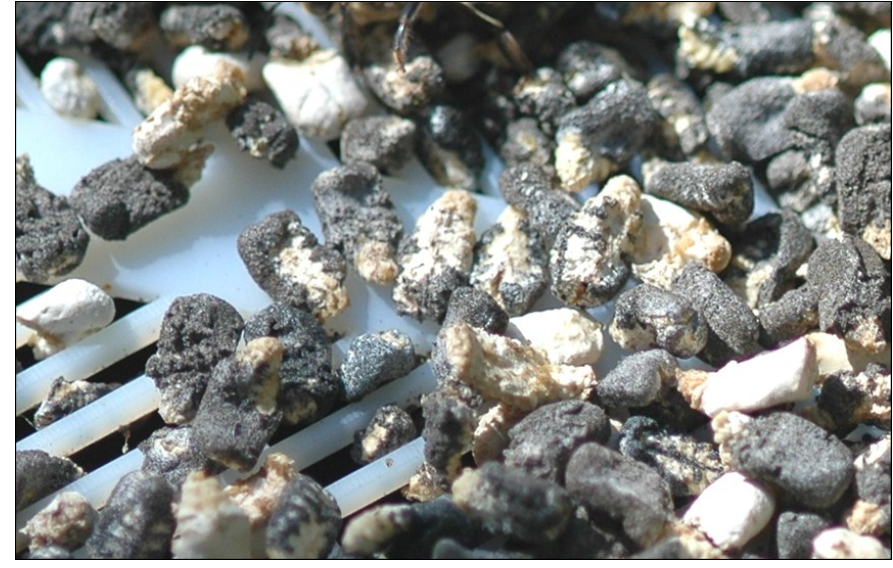

Fig. 2. Dark and white chalkbrood mummies. The black mummies contain millions of new infective spores.

Photo: A B Jensen

1988). As mentioned above, this is a heterothallic fungus with two mating types and only when + and - strains are grown in close proximity does the formation of fruiting bodies occur. The fruiting bodies are spherical spore cysts ( $47-140 \mu \mathrm{m}$ in diameter; Fig. 3a) which contain numerous spore balls $(9-19 \mu \mathrm{m}$, Fig. 3b) composed of hyaline spores (2.7 - 3.5 x $1.4-1.8 \mu \mathrm{m}$, Fig. 3c) (Skou, 1972; Bissett, 1988).

\subsubsection{Biological diagnosis}

Identification of the vegetative stages of the fungus can be done by a mating test with two reference strains (AFSEF 7405 and ARSEF 7406). Production of spore cysts with one of the reference strains would prove the identify of $A$. apis mating. The mating test is described under paragraph 1.4.1.4. Production and quality of inoculums

\subsubsection{Molecular methods}

The Polymerase Chain Reaction (PCR) has increasingly been used for detection of microorganisms. The internal transcribed spacer (ITS) region of the nuclear ribosomal repeat unit is the locus most often used for molecular identification of fungal species (Nilsson et al., 2008) and it is now accepted as the general fungal barcode marker (Schoch et al., 2012). Almost no variation between $A$. apis strain was detected in the ITS region (Anderson et al., 1998; Jensen et al., 2012) and several $A$. apis species specific primers have been designed targeting the ITS (Table 1). Irrespective of which primers are used, the presence of a band from PCR amplification indicates the presence of A. apis DNA.

DNA can be extracted with standard kits like DNeasy ${ }^{\circledR}$ Plant Mini Kit (Qiagen), Ultra Clean plant DNA isolation kits (Mo Bio Laboratories) or PrepMan Ultra reagent (Applied Biosystems) using the manufacturers' protocols (for other protocols of DNA extractions consult the BEEBOOK paper on molecular methods (Evans et al., 2013) 

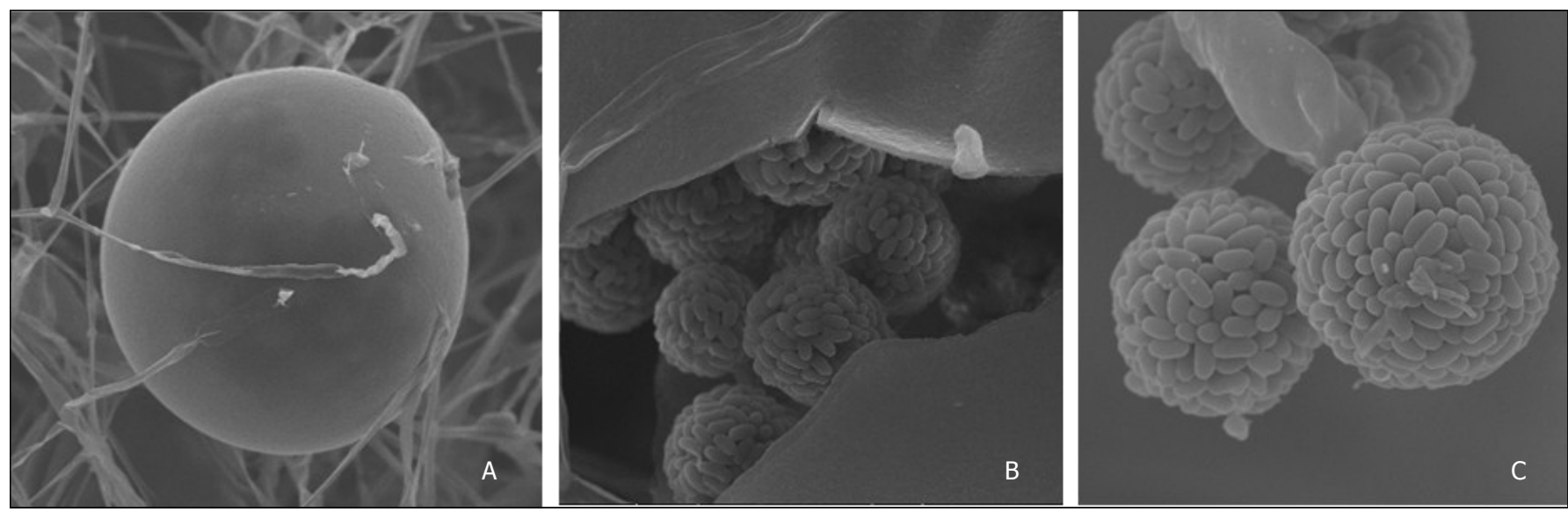

Fig. 3. Scanning electron microscope pictures of Ascosphaera apis fruiting body. A. Spherical fruiting body; $\boldsymbol{B}$. Cracked fruiting body with sporeballs; $\boldsymbol{C}$. Sporeballs with multiple ascospores.

Photos: J Bresciani and A B Jensen

\subsubsection{PCR for species identification}

Genomic DNA can be amplified in a $25 \mu$ reaction containing:

1. $2.5 \mu \mathrm{l}$ Taq polymerase buffer $(100 \mathrm{mM}$ tris- $\mathrm{HCl}, \mathrm{pH} 8.3 ; 500$ $\mathrm{mM} \mathrm{KCL}$ )

2. $2 \mathrm{U}$ of Taq DNA polymerase

3. $1.5-2.5 \mathrm{mM} \mathrm{MgCl}_{2}$

4. $250 \mu \mathrm{M}$ of each deoxyribonucleotide triphosphate

5. $0.25 \mu \mathrm{M}$ of an forward and reverse primer (Table 1 )

6. $1 \mu \mathrm{l}$ of DNA

Reaction conditions are as follows:

1. initial denaturing for $10 \mathrm{~min}$ at $94^{\circ} \mathrm{C}$

2. 30 cycles of $45 \mathrm{~s}$ denaturing at $94^{\circ} \mathrm{C}$

3. $45 \mathrm{~s}$ annealing at $62-65^{\circ} \mathrm{C}$

4. 1 min extension at $72^{\circ} \mathrm{C}$

5. final extension for $5 \mathrm{~min}$ at $72^{\circ} \mathrm{C}$.

Results are visualised using Gel Doc (BioRad) or any other DNA imaging systems. We would recommend that the primer pair 3-F1 and 3-R1 (Table 1) (James and Skinner, 2005) be used as a standard for identification of $A$. apis. Both primers are $A$. apis specific as opposed to the primer pair in Murray et al. (2005). Furthermore, 3-F1/3-R1 amplifies a longer PCR product that could be very useful for sequencing efforts (James and Skinner, 2005). The PCR protocol described above can be optimised depending on the type of equipment and reagents used in the laboratory. We would recommend sequencing the PCR product as a quality control, the first time the protocol is implemented in a new laboratory (for more information on sequencing consult the BEEBOOK paper on molecular methods (Evans et al., 2013).

\subsection{Quantitative detection}

\subsubsection{Quantify the level of fungal infection in bee colonies} Different methods have been used to assess the level of chalkbrood infection in the honey bee hive, but none of the methods are completely reliable. The most direct method is to remove brood combs from the hives and count the number of mummies inside capped and uncapped cells. These values can be added to the number of mummies found on the bottom board of the hive. It is however important to add an entrance hive trap like a pollen trap (see the BEEBOOK paper on miscellaneous methods (Human et al., 2013) or a screened bottom board (Flores, unpublished data), to hinder the bees from removing mummies from the hive.

Assessing chalkbrood infection by counting mummies has important drawbacks: it does not include the number of mummies inside capped cells, unless all capped cells are opened and inspected; and it does not include the mummies that are removed from the hive in small pieces by worker bees which are thus not collected by the entrance traps. Furthermore, these counting methods are heavily influenced by environmental conditions. High nectar flow induces higher removal of mummies (Thompson, 1964; Momot and Rothenbuhler, 1971) and during a nectar flow more mummies may be recovered in the traps, leading to possible error in the estimation of disease prevalence.

For the above reasons, we propose that the level of colony infection be evaluated by chilling the brood to $25^{\circ} \mathrm{C}$ (Flores et al., 1996a). The number of mummified larvae after chilling allows for an assessment of the degree of potential infection in bee colonies. This method has also been used to compare the degree of infection among

Table 1. List of Ascosphaera apis specific primers. * Primer pair recommended to be used as standard.

\begin{tabular}{|l|c|c|c|}
\hline Primer name & $\begin{array}{c}\text { Annealing } \\
\text { temp. }\left({ }^{\circ} \mathbf{C}\right)\end{array}$ & Primer sequence & Citation \\
\hline $3-F 1^{*}$ & 62 & TGTCTGTGCGGCTAGGTG & James and Skinner, 2005 \\
\hline $3-F 2$ & 62 & GGGTTCTCGCGAGCCTG & James and Skinner, 2005 \\
\hline $3-R 1 *$ & 62 & CCACTAGAAGTAATGATGGTTAGA & James and Skinner, 2005 \\
\hline AscoF3 & 64 & GCACTCCCACCCTTGTCTA & Murray et al., 2005 \\
\hline AapisR3 & 64 & CCCACTAGAAGTAAATGATGGTTA & Murray et al., 2005 \\
\hline
\end{tabular}


colonies before and after a treatment or as a routine colony inspection (Flores et al., 2001; 2004a). To minimize the effects of brood removal by workers, it is important to place the brood comb in an incubator, as described in paragraph 1.3.1.1.

\subsubsection{Procedure for quantifying the level of colony infection:}

1. Remove one brood comb from the hive containing $5^{\text {th }}$ instar larvae that have not yet been sealed (i.e., the larvae are close to being capped with wax)

2. Mark on a plastic transparency the area with these unsealed larvae (this step is only important if the frame also contains capped brood)

3. Return the brood comb to the colony

4. Remove the brood comb from the hive a maximum of 20 hours later

5. Cut a piece of comb containing at least 100 recently capped cells (capped within the last 20 hours). These larvae can be identified using the plastic transparency. (It is best to remove unsealed brood from the comb before placed in the incubator)

6. Place one or more pieces of comb with capped cells in an incubator at $25^{\circ} \mathrm{C}$ at approximately $65 \%$ humidity for 5 days. The chilling will ensure disease development. An open water bottle placed in the incubator will provide sufficient humidity

7. After 5 days, open all capped cells and record the results

8. Repeat the experiment three times to obtain individuals from enough patrilines and cover the variation in individual susceptibility to the fungus.

\subsubsection{Molecular methods $q P C R$}

In recent years, real-time PCR (RT-PCR) has been used to identify and quantify viral, bacterial and microsporidial pathogens in the honey bee (see the BEEBOOK papers on nosema (Fries et al., 2013), European foulbrood (Forsgren et al., 2013), viruses (de Miranda et al., 2013) and molecular methods (Evans et al., 2013)). There are, however, no methods yet available to quantify $A$. apis spores or the $A$. apis hyphal biomass.

\subsection{Production and quality of inoculums}

\subsubsection{Isolation techniques}

\subsubsection{Growth media}

In culture, $A$. apis isolates can grow on many different media such as potato-dextrose agar (PDA), yeast-glucose-starch agar (YGPSA), and Sabouraud dextrose agar) (Bailey, 1981; Heath, 1982; Anderson and Gibson, 1998; Hornitzky, 2001), but they grow very well on media with high sugar content like MY-20 (Udagawa and Horie, 1974).

MY-20:

1. Dissolve the following components in approximately $750 \mathrm{ml}$ deionised water:
- $4.0 \mathrm{~g}$ peptone

- 3.0 g yeast extract

- $200.0 \mathrm{~g}$ glucose

- $20.0 \mathrm{~g}$ agar

2. Adjust the final volume to $1000 \mathrm{ml}$.

3. Autoclave at $115^{\circ} \mathrm{C}$ for 15 minutes.

\subsubsection{Isolation of A. apis strains}

Ascosphaera apis can be isolated from fresh mummies or dry mummies collected directly from brood frames or mummies from the bottom board or hive entrance. Both white and dark mummies can be used, but it is generally easier with white mummies, since the latter will often readily produce spore cysts following incubation when

+ and - strains come into contact.

1. Surface sterilize the mummy in $10 \%$ sodium hypochlorite for 10 $\min$

2. Rinse the mummy twice in sterile distilled water for $2 \mathrm{~min}$

3. Cut the mummy into smaller pieces, place the pieces on an agar plate (SDA, PDA,YGPSA or MY20)

4. Incubate the plate in dark at $30-34^{\circ} \mathrm{C}$

5. Hyphal growth is visible usually within $2-4$ days Addition of antibacterial compounds (e.g. chloramphenicol, cycloheximide, streptomycin or dodine) in the media can be advantageous to prevent bacterial growth. Ascosphaera apis growth will often be inhibited, but once transferred back to non-antibiotic media it can be quickly recovered.

\subsubsection{Hyphal tip isolation of A. apis strains}

A single honey bee larva can ingest a large number of fungal spores, thus to ensure that the isolate is composed of a single strain, hyphal tip isolation is preferred (Fig. 4).

1. Place a dissecting microscope in a sterile hood and wipe with $70 \%$ ethanol

2. Use a fresh $A$. apis isolate (approx. $4 \mathrm{~cm}$ in diameter)

3. Find a single hypha at the edge of the culture under the microscope, and cut a hyphal tip just before the last branching point using a scalpel and a minutien pin

4. Transfer the tip to a new culture plate

5. Incubate the plate in darkness at $30-34^{\circ} \mathrm{C}$

\subsubsection{Mating test}

Once a single isolate is obtained, the mating type can be determined using a sexual compatibility test. We recommend that the two reference strains (AFSEF 7405 and ARSEF 7406) be used in the mating tests.

1. Cut agar plugs from the border of well growing isolates 

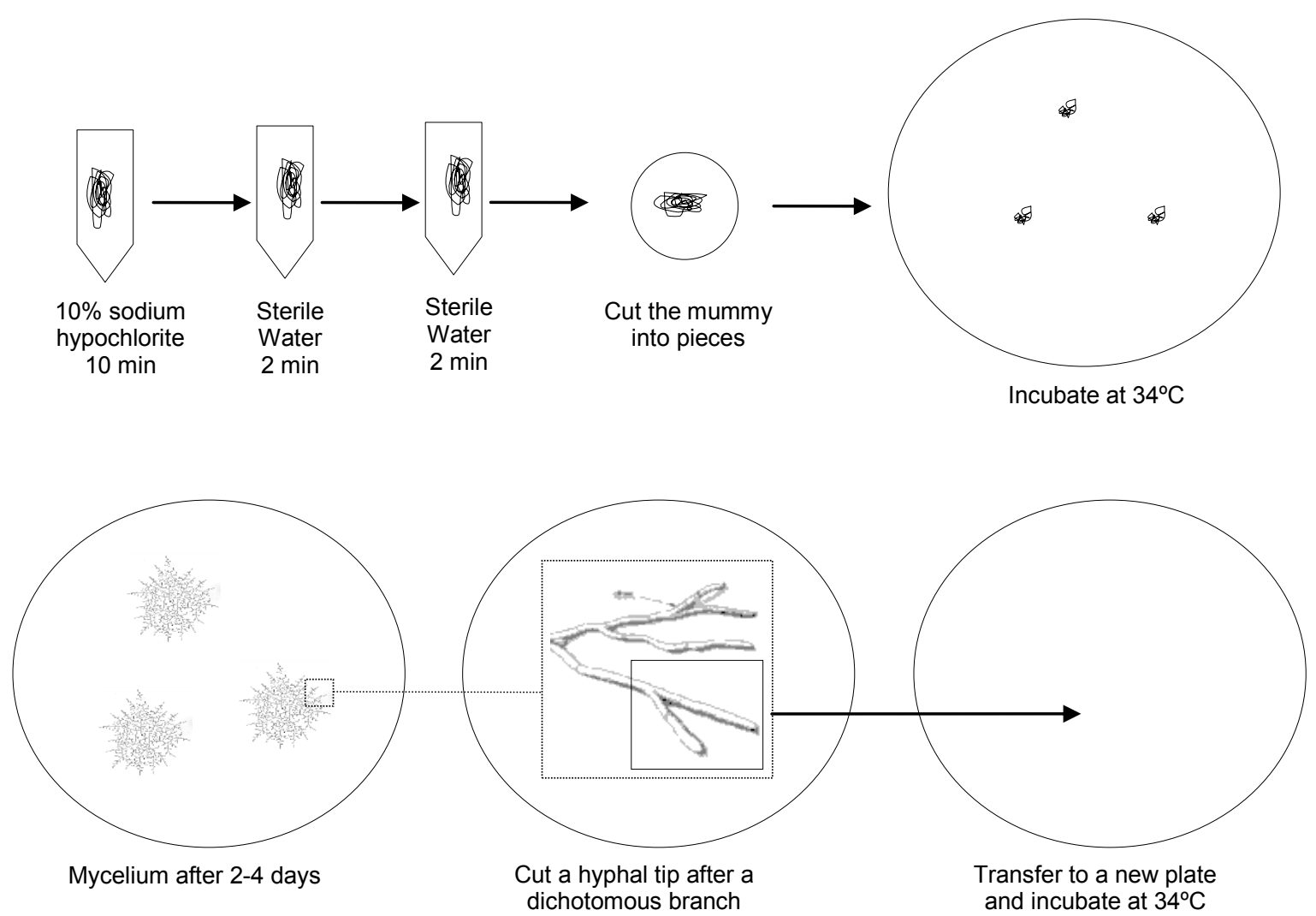

Fig. 4. Hyphal tip isolation of Ascosphaera apis.

2. Place the plugs of the new isolate between agar plugs of the two reference strains with a distance of approximately $4 \mathrm{~cm}$

3. Incubate the plate in darkness at $30-34^{\circ} \mathrm{C}$

4. After 5-7 days the presence of dark spore cysts (Fig. 5) normally can be observed as a black zone where hyphae of two strains with opposite mating types meet, indicating successful reproduction

5. If the test isolates are sexually compatible with the reference + strain, the other is the - mating type, or vice versa

On a standard agar plate (diameter $9 \mathrm{~cm}$ ) 4 new isolates can be tested simultaneously (Fig. 5).

\subsection{2. $P C R$ for strain differentiation}

Genetic variation is crucial for strain differentiation, and the arms race in host-pathogen relationships has been recorded with genetically different $A$. apis strains (Vojvodic et al., 2011b). The PCR fingerprinting method, using BOX, REP, and ERIC as random primers (Reynaldi et al., 2003), has been used to identify A. apis isolates, and microsatellite markers have been developed (Rehner and Evans, 2009). Recently several sequences of intergenetic regions or introns were screened. Three loci were found to be highly variable and can be used in identifying and differentiating $A$. apis strains (Jensen et al., 2012)
(Table 2). The advantages of DNA sequences of polymorphic loci with specific primers over the PCR fingerprinting and microsatellite markers is that the sequences produced in one study can easily be compared with those in another study.

\subsubsection{PCR}

Genomic DNA can be amplified in a $50 \mu$ reaction containing:

1. $10 \mu \mathrm{l}$ of $5 \mathrm{x} \mathrm{HF}$ buffer $\left(1.5 \mathrm{mM} \mathrm{MgCL}_{2}\right)$

2. $1 \mathrm{U}$ of Phusion ${ }^{\circledR}$ High-Fidelity DNA Polymerase (New England Biolabs, Inc)

3. $200 \mu \mathrm{M}$ of each deoxyribonucleotide triphosphate

4. $1 \mu \mathrm{M}$ forward and reverse primer (Table 2)

5. $1 \mu$ of DNA

Reaction conditions:

1. initial denaturing for $30 \mathrm{~s}$

2. denaturing at $98^{\circ} \mathrm{C}$

3. 10 touchdown cycles: $98^{\circ} \mathrm{C}$ for $30 \mathrm{~s}, 70-60^{\circ} \mathrm{C}$ (decrease of $1^{\circ}$ C per cycle) for $30 \mathrm{~s}$, and $72^{\circ} \mathrm{C}$ for $30 \mathrm{~s}$,

4. 30 cycles of $98^{\circ} \mathrm{C}$ for $30 \mathrm{~s}, 60^{\circ} \mathrm{C}$ for $30 \mathrm{~s}$, and $7^{\circ} \mathrm{C}$ for $30 \mathrm{~s}$;

5. $10 \mathrm{~min}$ extension at $72^{\circ} \mathrm{C}$. 
Table 2. List of qRT-PCR primers developed for targeting $A$. apis transcripts. The first three primer sets target genes that are involved in fungal mating and reproduction. Actin can be used as a reference gene.

\begin{tabular}{|l|c|c|c|}
\hline Primer name & $\begin{array}{c}\text { Annealing } \\
\text { temp. }\left({ }^{\circ} \mathbf{C}\right)\end{array}$ & Primer sequence & Citation \\
\hline Mat1-2-1 F & 62 & AAAATACCAAGGCCACCGA & Aronstein et al., 2007 \\
\hline Mat1-2-1 R & 62 & GGAGCATATTGGTAATTGG & Aronstein et al., 2007 \\
\hline Ste11-like F & 62 & GGGAAGATTGCCAGGCC & Aronstein et al., 2007 \\
\hline Ste11-like R & 62 & CAAACTTGTAGTCCGGATG & Aronstein et al., 2007 \\
\hline Htf F & 62 & AAAATCCCAAGGCCTCGTA & Aronstein et al., 2007 \\
\hline Htf R & 62 & CTGGTAGCGGTAGTCAGG & Aronstein et al., 2007 \\
\hline Actin_Aapis F & 58 & CATGATTGGTATGGGTCAG & Aronstein et al., 2007 \\
\hline Actin_Aapis R & 58 & CGTTGAGGTCTCGAAGAC & Aronstein et al., 2007 \\
\hline
\end{tabular}

Amplified products can be analysed on a $1.5 \%$ (wt/vol) agarose gel stained with ethidium bromide or EZ-vision dye. Alternatively, PCR results could be visualised using DNA imaging. Sharp bands can be sequenced directly (further advice on sequencing and analyses can be found in the BEEBOOK paper on molecular methods (Evans et al., 2013). Note: Alternatively another polymerase can be used and the touch down step can be replaced by adding five normal cycles; however, it will require some optimization.

\subsubsection{Preservation of in vitro cultures}

An $A$. apis isolate starts to show signs of aging after 30 days of growth (Ruffinengo et al., 2000) and thus requires monthly transfer. However, frequent culture transfers are expensive, time consuming and increase the risk of contamination. In addition, $A$. apis isolates, as seen for many other microbes, can lose virulence when kept in culture with repeated transfers, thus it is important to utilize a long term storage method soon after an isolate is obtained. Two different culture preservation methods have been successfully used: cryopreservation (Jensen et al., 2009a) and propagation on Integral Rice Kernels (IRK) (Palacio et al., 2007). Contamination during storage seems to be less risky during cryopreservation at $-80^{\circ} \mathrm{C}$, however for larger quantities and for laboratories not equipped with cryopreservation capacity, the use of rice kernels is a great alterative.

\subsubsection{Cryopreservation in glycerol at $-80^{\circ} \mathrm{C}$}

1. Cut three plugs from the border of a growing agar colony and put the plugs in a cryogenic vial containing $1 \mathrm{ml} 10 \%$ sterile glycerol

2. Place the vials in a Cryo $1^{\circ} \mathrm{C}$ Freezing container, "Mr. Frosty" (Nalgene Co; Rochester, NY). Mr. "Frosty" ensures a $1{ }^{\circ} \mathrm{C} / \mathrm{min}$ cooling rate

3. Set the "Mr. Frosty" at $5^{\circ} \mathrm{C}$ for 4 hours and then in $-80^{\circ} \mathrm{C}$ for 24 hours

4. After 24 hours transfer the vials to standard freezer boxes

5. Store at $-80^{\circ} \mathrm{C}$ until use

6. Upon use, thaw the vial in a $34^{\circ} \mathrm{C}$ water bath and place the hyphal plugs on new agar plates
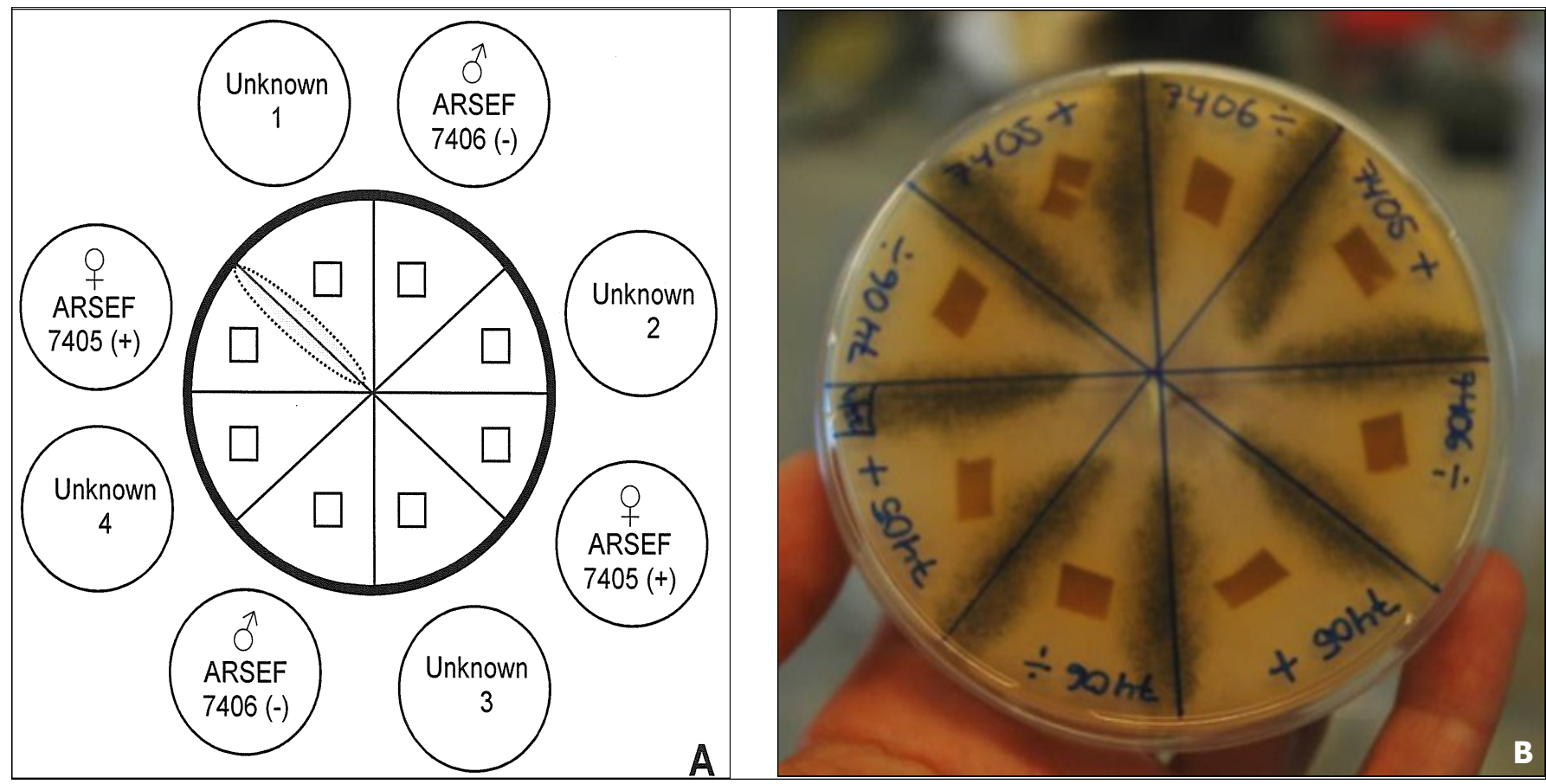

Fig. 5. Ascosphaera apis mating test and production of inoculums. A. Mating test with four isolates of unknown mating types. Unknown 1 mates with ARSEF $7405(+)$ and therefore harbours the opposite mating type (-). B. Production of inoculums between two isolates of opposite mating types. Fruiting bodies with spores inside are formed where the hyphae meet (black zone).

Photo: A B Jensen 


\subsubsection{Integral Rice Kernels (IRK) storage}

1. Autoclave ( 1 atmosphere and $120^{\circ} \mathrm{C}$ for $15 \mathrm{~min}$ ) $25 \mathrm{~g}$ moistened IRK (2:1 wt/vol) in Petri dishes (9-cm diameter)

2. Inoculate the IRK with 4-mm diameter plugs from the border of a growing agar colony

3. Incubate at $30^{\circ} \mathrm{C}$ for 15 days

4. Store the IRK at $19^{\circ} \mathrm{C}$ until use

\subsubsection{Spore production}

Ascosphaera apis spores are the only infective units of chalkbrood. It is essential to have a high quantity and quality of spores for experiments; e.g. for testing antifungal compounds or for breeding experiments. Spores can be retrieved from black mummies or produced in vitro. From a standardization point of view, the use of in vitro spores from reference strains are strongly recommended, but spores retrieved from black mummies might be chosen in certain situations. Ascosphaera apis will mate on various media but the yield of spores is increased on malt yeast with $20 \%$ dextrose agar (MY20) (Ruffinengo et al., 2000). It is recommended that a fresh spore solution be made for every experiment.

\subsubsection{Production and harvest of in vitro spores}

1. Cut agar plugs from the border of well-growing isolates with different mating types

2. Place the plugs of the + and - strain a distance of approximately $4 \mathrm{~cm}$ on MY20 agar (see paragraph 1.4.1.1.)

3. Incubate the plate in the dark at $30-34^{\circ} \mathrm{C}$ at least 3 weeks to ensure production of mature spores

4. Use a scalpel to scrape off the spore cysts from the black mating stripes

5. Transfer them to a glass mortar with a ground-glass pestle (glass tissue grinder; Fig. 6a and b)

6. Add $5-10 \mu$ sterile water and grind the suspension $1 \mathrm{~min}$ to release spores from the spore cysts and balls
7. Add $50 \mu \mathrm{l}$ sterile water and grind again $1 \mathrm{~min}$

8. Add $200 \mu \mathrm{l}$ sterile water to the mortar

9. Pipette spores from the mortar into an $1.5 \mathrm{ml}$ Eppendorf tube

10. Add additional $750 \mu \mathrm{l}$ water to get a medium density of spores

11. Let large particles, unbroken sporocysts, spore clumps etc. in the suspension settle for $30 \mathrm{~min}$

12. Pipette, from just below the surface, approximately $500 \mu \mathrm{l}$ into a new tube, which should contain mostly released individual spores

13.Prepare a dilution series to $10^{-2}$ or $10^{-3}$ for counting and calculating the concentration of the undiluted suspension with a haemocytometer (refer to the BEEBOOK paper on miscellaneous methods (Human et al., 2013).

\subsubsection{Harvest of in vivo spores}

1. Mix black mummies with $5 \mathrm{ml}$ of sterile distilled water

2. Shake for $5 \mathrm{~min}$

3. Homogenize the spore solution with a glass tissue grinder for 5 $\min$

4. Centrifuge to spin-dry at $3500 \mathrm{rpm}$ for $5 \mathrm{~min}$

5. Discard the supernatant

6. Add $5 \mathrm{ml}$ iodine-povidone (50\% in distilled sterile water). Iodine-povidone is added to avoid bacterial contamination

7. Shake for $10 \mathrm{~min}$

8. Centrifuge to spin-dry at $3500 \mathrm{rpm}$ for $5 \mathrm{~min}$

9. Discard the supernatant

10. Wash three times by adding $5 \mathrm{ml}$ of sterile distilled water

11. Shake for $5 \mathrm{~min}$

12.Spin-dry at $3500 \mathrm{rpm}$ for $5 \mathrm{~min}$

13.Add $1 \mathrm{ml}$ water

14. Prepare a dilution series to $10^{-2}$ or $10^{-3}$ for counting and calculating the concentration of the undiluted suspension with a haemocytometer (refer to the BEEBOOK paper on miscellaneous methods (Human et al., 2013).

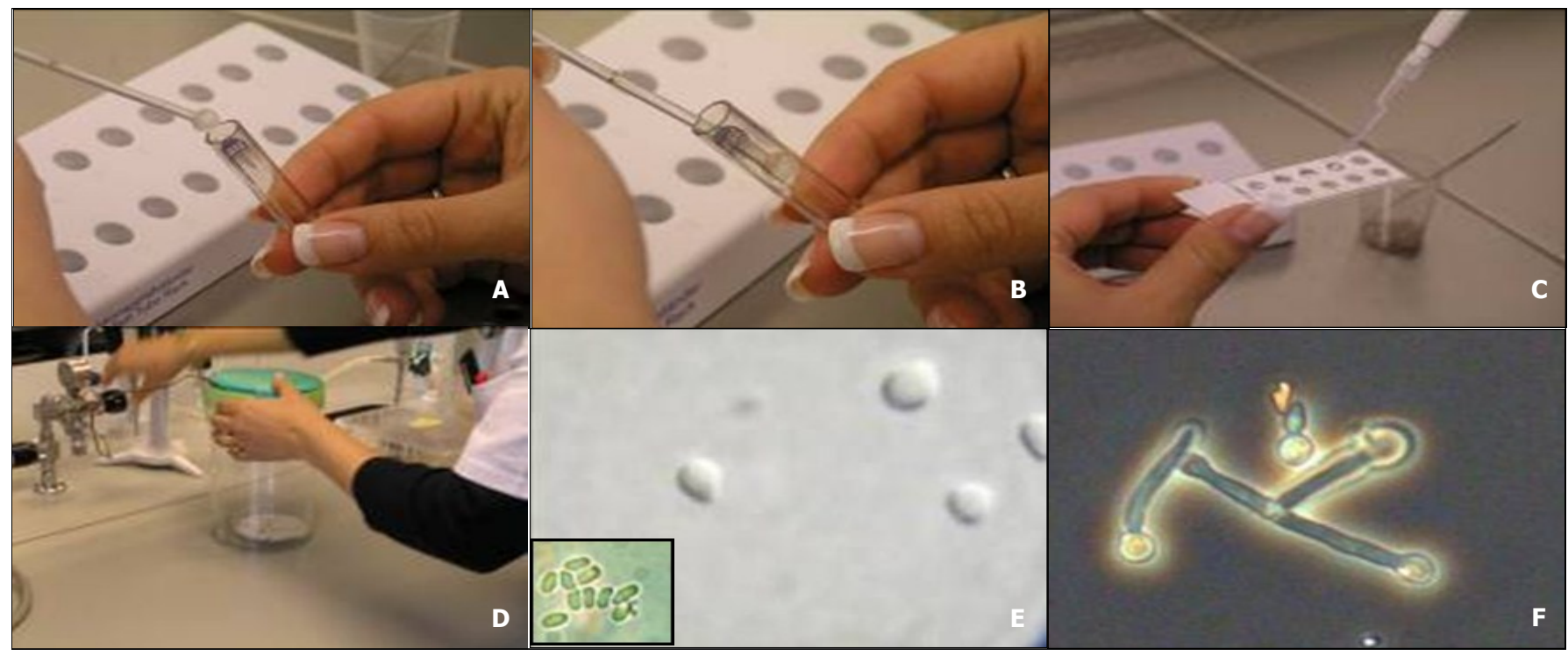

Fig. 6. Spore germination test: $\boldsymbol{A} \boldsymbol{\&} \boldsymbol{B}$. First grind the sporocysts to release spores from cysts and balls; $\boldsymbol{C} \boldsymbol{\&} \boldsymbol{D}$. incubate the spores in liquid medium and flush with $\mathrm{CO}_{2}$ incubate the spores 32 hours at $34^{\circ} \mathrm{C} ; \boldsymbol{E} \boldsymbol{\&} \boldsymbol{F}$. check for spore enlargement. 
Spores from mummies can also be harvested using the in vitro harvest method described above. To get a better homogenization, scrape the spore cysts from the outside of the mummy before grinding. In vivo spores must be used the same day they are prepared, due to the presence of other microorganisms on the mummies even though the broad-spectrum bactericide iodine-povidone is used to avoid bacterial contamination in the spore solution preparation. Dry dark mummies with viable spores can be preserved for several years (at least 9 years) when stored dry in a closed bottle (Flores, pers. comm.)

\subsubsection{Quality test of inoculums}

Chalkbrood spores can contaminate all surfaces of the bee hive and accumulate in hive products. They are very resistant to the environment and can remain viable and infective for more than 15 years (Toumanoff, 1951). However, spore viability will decline over time and this will vary from isolate to isolate and from batch to batch. Thus it is important to check spore viability prior to an experiment.

\subsubsection{Spore viability and germination test (Fig. 6)}

1. Place a sterile Teflon coated slide in a sterile petri dish lined with wet filter paper

2. Prepare a concentration of $2.0 \times 10^{7}$ spores per $\mathrm{ml}$

3. Mix $100 \mu \mathrm{l}$ spore suspension with $500 \mu \mathrm{l} \mathrm{GLEN} \mathrm{(see} \mathrm{recipe}$ below)

4. Place $10 \mu$ l of the GLEN / spore mix onto the spot of the Teflon coated slides

5. Place the petri dish in an airtight container and flush with $\mathrm{CO}_{2}$ $30 \mathrm{sec}$ to ensure a minimum of $10 \% \mathrm{CO}_{2}$

6. Incubate 32 hours at $34^{\circ} \mathrm{C}$

7. Add a cover slip and count the spores directly on the Teflon slide under a microscope at 400 magnification

8. Evaluate 100 spores for enlargement or germ tube formation in three different fields of view on the slide

The AnaeroGen system (Oxoid; Basingstoke, UK) has been used with success in cases where the laboratory is not equipped with $\mathrm{CO}_{2}$. A packet is placed together with the petri dish in a sealed jar and will generate 9 to $13 \% \mathrm{CO}_{2}$.

\subsubsection{GLEN medium}

1. Dissolve the following components in approximately $900 \mathrm{ml}$ deionised water:

- $4.000 \mathrm{~g}$ glucose-dextrose

- $7.680 \mathrm{~g}$ natrium chloride

- $6.500 \mathrm{~g}$ lactalbumin hydrolysate

- $5.000 \mathrm{~g}$ yeast extract

- $1.952 \mathrm{~g}$ MES-buffer (2-(N-morpholino)ethanesulfonic acid)

2. Adjust the $\mathrm{pH}$ to 7.0 using $1 \mathrm{M} \mathrm{NaOH}$

3. Readjust the volume to $1000 \mathrm{ml}$

4. Sterilize by autoclaving at $121^{\circ} \mathrm{C}$ for 20 minutes.

\subsubsection{Availability and recommended reference isolates}

Microbial isolates including fungi are deposited and stored in several culture collections around the world. They are available for both commercial and scientific use. Isolates can be ordered from the culture collection for a fee that is usually lower for non-profit organizations. We would recommend that researchers deposit isolates that have been used in publications in one of these culture collections, so that they can be retrieved for future research.

Different strains of $A$. apis have shown variable virulence towards honey bees (Vojvodic et al., 2011a) and may also vary in other biological traits. Thus to be able to compare different studies we recommend to always use AFSEF 7405 and ARSEF 7406 as reference isolates. These two isolates have been involved in the $A$. apis genome sequencing project (Qin et al., 2006); they represent each of the two mating types and both can readily be retrieved from either the USDAARSEF or the ATCC culture collections.

Below is the list of the three most important culture collections we recommend for retrieving $A$. apis isolates:

USDA-ARSEF; ARS Collection of Entomopathogenic Fungi (7 isolates deposited, March 2012)

http://www ars usda gov/Main/docs htm?docid=12125

ATCC; American Type Culture Collection (9 isolates deposited, March 2012) http://www lgcstandards-atcc org/

CBS; Centraalbureau voor Schimmelcultures (7 isolates deposited, March 2012)

http://www cbs knaw nl/

\subsection{Infection bioassays}

A bioassay is a measurement of the effect of a substance on living organisms. Bioassays with $A$. apis can be conducted using in vitro reared larvae or directly in colonies. An in vitro bioassay has very important advantages over the whole colony bioassay; mainly, it excludes the effects of social immunity and allows for replicable experiments in controlled environment. However, to address questions related to hygienic behaviour, bioassays must be conducted directly within honey bee colonies.

\subsubsection{Infection bioassays using in vitro rearing of larvae}

Difficulties associated with controlling experimental conditions using honey bee colonies prompted the development of in vivo rearing conditions that allow rearing honey bee larvae in the laboratory and also a way to test the effects of pathogens, toxins and drugs. Refer to the $B E E B O O K$ paper on larval rearing for a detailed protocol (Crailsheim et al., 2013). Exposure bioassays of in vitro reared larvae have been used to test differences in virulence of various $A$. apis strains (Vojvodic et al., 2011b), to compare the temperature response of chalkbrood and stonebrood (Vojvodic et al., 2011a), to test susceptibility of various honey bee subspecies towards $A$. apis (Jensen et al., 2009b), to test virulence of $A$. apis with or without presence of other 
Ascosphaera species commonly associated with solitary bees (Vojvodic et al., 2012) and to explore the host response to infection of A. apis at the molecular level (Aronstein et al., 2010).

Ascosphaera apis spores have to be ingested by the larvae, hence they must be incorporated in the larval food. There are two ways spores can be administered - either the larvae can be fed a small quantity $(5 \mu \mathrm{l})$ of spore contaminated diet, which they will ingest quickly, or the larvae can be fed spore-contaminated diet ad libitum for a certain period. The advantage of feeding small quantities is that the exact dose per larvae can be controlled, and if fed with different dosages an exact $\mathrm{LD}_{50}$ can be calculated (Jensen et al., 2009b). Depending on the larval ages, additional feeding has to be done on the same day, approximately 2 hours later, after the first $5 \mu$ is consumed. However if the aim is to produce a high numbers of infected individuals it can be more efficient to use surplus diet, as it is less time consuming.

All larval instars can be infected by $A$. apis (Jensen, unpublished), but it is recommended to use $2^{\text {nd }}-4^{\text {th }}$ instar larvae. When using $5^{\text {th }}$ instar larvae, the $A$. apis spores have a limited time period in the gut for germination and penetration of the gut wall before the bee defecates, and $1^{\text {st }}$ instar larvae are very fragile.

\subsubsection{Infection bioassay of colonies}

When it is necessary to provoke chalkbrood infection in bee colonies, it may be sufficient to infect a group of larvae, or it may be necessary to cause widespread disease in the colony. The procedure differs for each case. In the first case, the larvae are directly fed sporecontaminated food. In the second case, the entire colony is exposed to spores either by spraying, feeding sugar/honey with spores or feeding pollen patties with spores (Moffett et al., 1978; Flores et al., 2004a). Flores et al. (2004a) evaluated different ways to inoculate colonies with $A$. apis spores using pieces of comb containing bee brood that have been subjected to controlled chilling. A mummification of $90.63 \%$ of the brood was reached by spraying water containing spores over combs, and colonies fed spore-pollen mixtures reached $86.32 \%$ infection. The use of sugar syrup with spores only reached $60.13 \%$ mummification and proved to be less effective. We recommend spraying or feeding inoculated pollen since these methods have proven to be most effective.

\subsubsection{Direct exposure of individual larvae}

1. Prepare a spore solution of $2 \times 10^{8}$ spores $/ \mathrm{ml}$ in sterile distilled water.

2. Mix (1:1, v:v) of the solution with honey food ( $50 \%$ honey : $50 \%$ distilled sterile water)

3. Remove sections of comb containing $5^{\text {th }}$ instar larvae from the hive.

4. Supply each of the $5^{\text {th }}$ instar larvae with $5 \mu$ l of contaminated food (equals a dose of $5 \times 10^{5}$ spores per larvae)
5. Place the food near the mouthpart. Use extreme care to avoid touching the larvae and confirm consumption by direct observation

6. Immediately after feeding, store the pieces of comb for 2 hours at $25^{\circ} \mathrm{C}$

7. Return the comb to the hive so that the bees will cap the cells containing the inoculated larvae

8. Remove the comb a maximum of $\mathbf{2 0}$ hours later and store it at $25^{\circ} \mathrm{C}$ and approximately $65 \%$ humidity for 5 days. The chilling of the larvae will ensure disease development. An open water bottle placed in the incubator will provide sufficient humidity

9. After 5 days open all cell cappings and record the results. (See paragraph 3.1. Quantify infection degree in colonies)

\subsubsection{Infection of colonies with a water spore suspension}

1. Prepare a spore solution of $1.25 \times 10^{7} \mathrm{spores} / \mathrm{ml}$ in sterile distilled water. (See paragraph 1.4. Production and quality of inoculums)

2. Spray $10 \mathrm{ml}$ on the each brood comb surface This quantity has been used successfully on colonies with $8-10$ combs (Flores et al., 2004a).

\subsubsection{Infection of colonies with spores in pollen}

1. Prepare a spore solution of $1.25 \times 10^{7}$ spores $/ \mathrm{ml}$ in sterile distilled water. (See paragraph 1.4.3. and 1.4.4. Production and quality of inoculums)

2. Add $100 \mathrm{ml}$ spore solution to $150 \mathrm{~g}$ pollen

3. Distribute the mixture on the top of the combs

An alternative method, if spore concentration is not very important, is to homogenize 15 black mummies and mix with $150 \mathrm{~g}$ pollen.

\subsection{Expression of fungal genes}

Studies investigating host-pathogen interactions have taken a new dimension utilizing mRNA quantification (qRT-PCR). Here we describe qRT-PCR approach used for identification of $A$. apis mating type idiomorphs and quantification of $A$. apis transcripts in culture and in host tissue (Aronstein et al., 2007).

Total RNA can be isolated using standard kits, TRIzol (Invitrogen; Carlsbad, California) and RNeasyR Mini Kit (Qiagen; Valencia CA). These reagents have been used successfully to make cDNA from mycelia or honey bee larvae (Aronstein et al., 2007; 2010), for RNA extraction method, see the BEEBOOK paper on molecular methods (Evans et al., 2013)

\subsection{1. $q R T-P C R$ for quantification of $A$. apis transcripts}

1. CDNA can be amplified in a $20 \mu \mathrm{l}$ reaction containing, 1.1. $\quad 1.0 \mathrm{U}$ of GoTaq ${ }^{\circledR}$ Flexi DNA polymerase (Promega Co; Madison, WI),

1.2. $5 \times$ GoTaq $^{\circledR}$ Flexi buffer 
Table 3. List of qRT-PCR primers developed for targeting $A$. apis transcripts. The first three primer sets target genes that are involved in fungal mating and reproduction. Actin can be used as a reference gene.

\begin{tabular}{|l|c|c|c|}
\hline Primer name & $\begin{array}{c}\text { Annealing } \\
\text { temp. }\left({ }^{\circ} \mathbf{C}\right)\end{array}$ & Primer sequence & Citation \\
\hline Mat1-2-1 F & 62 & AAAATACCAAGGCCACCGA & Aronstein et al., 2007 \\
\hline Mat1-2-1 R & 62 & GGAGCATATTGGTAATTGG & Aronstein et al., 2007 \\
\hline Ste11-like F & 62 & GGGAAGATTGCCAGGCC & Aronstein et al., 2007 \\
\hline Ste11-like R & 62 & CAAACTTGTAGTCCGGATG al., 2007 \\
\hline Htf F & 62 & AAAATCCCAAGGCCTCGTA & Aronstein et al., 2007 \\
\hline Htf R & 62 & CTGGTAGCGGTAGTCAGG & Aronstein et al., 2007 \\
\hline Actin_Aapis F & 58 & CATGATTGGTATGGGTCAG & Aronstein et al., 2007 \\
\hline Actin_Aapis R & 58 & CGTTGAGGTCTCGAAGAC & Aronstein et al., 2007 \\
\hline
\end{tabular}

1.3. $0.25 \mathrm{mM}$ dNTP mix,

1.4. $2.5 \mathrm{mM} \mathrm{MgCl}_{2}$,

1.5. $0.3 \mu \mathrm{M}$ of each primer,

1.6. $0.75 \mu$ of a $1 / 1000$ stock dilution of SYBR-Green (Invitrogen Corp),

1.7. $1 \mu \mathrm{l}$ of CDNA

2. Reaction conditions are as follows:

2.1. Initial denaturing at $95^{\circ} \mathrm{C}$ for $3 \mathrm{~min}$,

2.2. 40 cycles at $95^{\circ} \mathrm{C}(20 \mathrm{~s}), 58-62^{\circ} \mathrm{C}(30 \mathrm{~s})$ depending on the gene (Table 3 ) and $72^{\circ} \mathrm{C}(30 \mathrm{~s})$.

Negative controls (all reaction components except the DNA which is replaced with water) must be included in each run.

3. For standardization and normalization against housekeeping genes and data analysis, see the BEEBOOK paper on molecular methods (Evans et al., 2013).

\subsection{Hygienic behaviour}

Hygienic behaviour is defined as the bees' ability to detect and remove diseased brood from the nest (Rothenbuhler, 1964). Hygienic behaviour was first described in the 1930s when researchers sought to determine the mechanism by which some honey bee colonies were resistant to American foulbrood (reviewed in Spivak and Gilliam, 1993). In the 1980s, it was shown that hygienic behaviour was also the primary mechanism of resistance to chalkbrood (Gilliam et al., 1983), although resistance to this disease involves other factors as well, such as differences in the susceptibility of different colonies or even between patrilines within colonies (Invernizzi et al., 2009; Jensen et al., 2009b).

Hygienic behaviour assays, involving killing brood by freezing or by piercing pupae with a pin (methods described in the BEEBOOK paper on queen rearing and selection (Büchler et al., 2013)) are indirect, and record the proportion of dead brood removed by a colony after a particular amount of time. Most, but not all colonies, show a good correlation between removal of freeze-killed brood and resistance to chalkbrood. However, researchers and beekeepers cannot assume that the ability of a colony to remove dead brood within a certain time will ensure colony-level resistance to chalkbrood. It is very important, especially for breeding purposes, to directly challenge colonies with $A$. apis in addition to the freeze-kill or pin-kill brood assay (See paragraph 1.5.1. Infection bioassay of colonies) and subsequent observation of the bees' response to the challenged brood (Palacio et al., 2010).

\subsection{Olfactory detection}

Bees from hygienic colonies are particularly responsive to olfactorybased stimuli associated with diseased brood. All bees can perform uncapping and removal behaviours, but bees that detect abnormal brood odours at a low stimulus level may rapidly initiate uncapping behaviour, resulting in the removal of diseased brood before it becomes infectious (Wilson-Rich et al., 2009). Individual bees from rapid-hygienic line breeds exhibited significantly increased sensitivity to the odour of chalkbrood disease at lower concentrations compared with bees from the slow-hygienic line, based on electrophysiological recordings of nerve impulses from the antennae (EAG), by proboscisextension response conditioning (PER), and by isolation of volatiles from chalkbrood-infected larvae for use in field bioassays (see detailed methods in: Masterman et al., 2000, 2001; Gramacho and Spivak, 2003; Spivak et al., 2003; Swanson et al., 2009; and general methods of EAG and collection of volatiles in the BEEBOOK paper on chemical ecology methods (Torto et al., 2013) and of PER in the BEEBOOK paper on behavioural methods (Scheiner et al., 2013)).

\subsection{Inhibitory assays against chalkbrood}

For both fundamental and applied research it can be important to test the inhibitory effects of certain chemicals, plant extracts, propolis, probiotic bacteria or hemolymph against chalkbrood. These substances can be tested for their direct effect on spore germination and on hyphal growth, or they can be used to test their effect on the ability of the fungus to infect individual bees in vitro or in a colony context. 


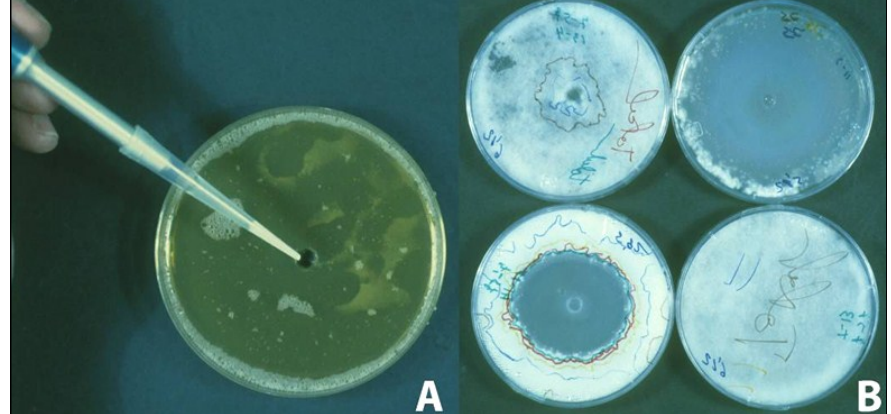

Fig. 7. Zone of inhibition assay of different compounds against

Ascosphaera apis. A. MY-20 medium with spores spread on the entire surface and with a central hole for the test compound; $\boldsymbol{B}$. The zone of inhibition was recorded daily by drawing on the Petri dish, a line over the border of the mycelium (each day a different colour) and the antifungal property was assessed as daily inhibition zone using an image analyser.

Photos: J M Flores

\subsubsection{Inhibition of spore germination and hyphae (zone of inhibition)}

1. Prepare MY20 medium (see paragraph 1.4.1.1.) in petri dishes $(15 \mathrm{~cm})$

2. Spread $2 \mathrm{ml}$ of a spore solution $\left(9.0 \times 10^{7}\right.$ spores $\left./ \mathrm{ml}\right)$ on the surface of the medium, approximately $10^{6} \mathrm{spores} / \mathrm{cm}^{2}$

3. Make a central hole $(7 \mathrm{~mm})$ in the MY20 medium (Fig. 7A)

4. Place $0.5 \mathrm{ml}$ of the test product into the hole

5. Incubate the cultures $\left(30^{\circ} \mathrm{C}, 12 \% \mathrm{CO}_{2}, 65 \%\right.$ relative humidity)

6. Measure the fungal growth (or the zone of inhibition) (Fig. 7B) Measure the fungal growth (or the zone of inhibition) daily using a stereoscopic microscope magnification (X 20 to 40). Mycelium growth can be seen within the medium before emerging at the surface (Puerta et al., 1990). An Image Analyzer can be used to measure the diameter of the zone of inhibition.

\subsubsection{Inhibition in colonies}

1. Assess the degree of infection in colonies before treatment, as described in paragraph 1.3.1. (Quantify infection degree in colonies)

2. Increase colony infection with $A$. apis as described in paragraph 1.5.2. (Infection bioassay of colonies)

3. Apply the test item to the colony

4. Assess the level of infection in the colony, as described in paragraph 1.3.1. (Quantify infection level in colonies) the next day after treatment and repeat the assessment depending of the aim of the experiment.

We propose an indirect assessment of in vivo treatments because quantifying the disease by counting mummies is very difficult and inaccurate. If the disease is increasing in the colony, the spore numbers will also increase; likewise, if the disease is decreasing, the spore number will be lower due to the natural behaviours of the bees such as hygienic removal of larvae. The degree of infection would most probably be related to the dynamics of $A$. apis spore load in the colony. Evaluation of the level of infection in the colony before and after treatment is therefore recommended.

\subsection{Minimizing chalkbrood in experimental colonies}

The main techniques for chalkbrood control lie in management practices that reduce spore concentration in the colonies and that avoid stress (in particular chilling) of susceptible brood.

\subsubsection{Breeding for resistance}

Gilliam et al., (1983) and Taber (1986) demonstrated that it is possible to select and breed honey bees for resistance to chalkbrood disease. Spivak and Reuter (2001) demonstrated that colonies selected for rapid removal of freeze-killed brood showed resistance to chalkbrood in field experiments. Palacio et al. (2000) observed that hygienic colonies had a lower frequency of brood diseases including chalkbrood. Commercial queen breeders in the US and Denmark have found that if they have "zero-tolerance" for chalkbrood; i.e. they never raise queens from a colony that has had clinical symptoms of chalkbrood and they simultaneously select for rapid hygienic behaviour then they get rather chalkbrood resistant lines (Spivak and Jensen, unpublished).

\subsubsection{Management and treatment}

There are a number of management's techniques that can be used to minimize the effects of chalkbrood in infected colonies:

1. Reduce volume of the brood chamber for the overwintering (Seal, 1957)

2. Enlarge colony entrance to aid ventilation (Gochnauer et al., 1975)

3. Replace old combs (Betts, 1951)

4. Heat treatment of the wax (Flores et al., 2005a)

5. Requeen affected colonies (Lunder, 1972)

To date, there is no effective chemical treatment against this disease. Nevertheless in vitro (Puerta et al., 1990; Flores et al., 1996b) and in vivo (Flores et al., 2001) techniques have been used to evaluate

\section{Stonebrood}

\subsection{Introduction}

Stonebrood is a very rare honey bee brood disease caused by several fungi from the genus Aspergillus. The disease was first described by Massen (1906) and has since then been found worldwide. Aspergillus flavus has most frequently been reported, followed by Asp. fumigatus, but also Asp. niger and other species can kill honey bees (Gilliam and Vandenberg, 1997). Aspergillus is able to infect the host through the 
gut if the spores are ingested, but also through the cuticle. Therefore, adults as well as larvae and pupae can become infected. In addition, most species of Aspergillus produce aflatoxins that have been suggested to be the primary cause of death in stonebrood infected honey bees (Burnside, 1930). However, a non-aflatoxin producing Asp. flavus strain has been observed to induce stonebrood symptoms equally well in in vitro reared honey bee larvae as afaltoxin producing strains (Vojvodic, unpublished).

Aspergillus spp. are cosmopolitan filamentous fungi often found in soil, where they thrive as saprophytes, but occasionally they do infect living hosts including, plants, insects and mammals. Aspergillus can infect human lungs, eyes, pharynx, skin and open wounds, but most commonly this has been observed in immune deprived individuals (Gefter, 1992; Germaud and Tuchais, 1995; Denning, 1998;

Galimberti et al., 1998; Garret et al., 1999). In addition, the alfatoxins are carcinogenic if inhaled or ingested; therefore precautions need to be taken when stonebrood disease occurs in honey bees principally to protect beekeepers and consumers. In several countries stonebrood is a notifiable disease that has to be reported to the authorities if it occurs.

\subsection{Biohazards}

Working with fungi requires good microbiological practice and containment, irrespective of whether they possess a potential risk for the environment or human, since proliferation on the growth medium of contaminants always poses a potential risk. Good microbiological practice is in principle the handling of a microorganism in a "test tube" without any other organisms entering and contaminating it.

Containment is in principle the handling of a microorganism with emphasis on safety of the laboratory worker and the environment. Good microbiological practice and containment involves:

Aseptic techniques

- Limit the open time of "test tube"

- Open tubes or plates only in bio-safe cabinet/bench to avoid

- contamination

- Only use sterile tools (e.g. pipette tips or loops)

- Avoid casual contact with the bench, fingers, or outside of the bottle

- Dispose or decontaminate tools immediately after use Personal hygiene and dress

- Wash hands prior to and following manipulations

- Wear appropriate personal protective equipment (gloves, clean lab coats)

- Do not touch the skin, face, or unclean non-sterile surfaces

- Confine loose or long hair and keep fingernails short

Area cleanliness and organization

- Disinfect work area before and after work with $70 \%$ Ethanol

- Immediately clean spills, and then disinfect the work surface

- Keep only items important for the task in progress in the bench
- Plan and lay out work in a logical order so the work in the bench becomes efficient

- Minimize personnel traffic and unnecessary movements around the work area

- Routine cleaning of difficult-to-access areas to prevent build up of dust and debris

Aspergillus spp. produce airborne conidia which represent a potential risk for the experimenter, but no additional attention has to be taken as long as good microbiological practice and containment are followed. In particular, it is important that the cultures grown on agar plates are only opened in a sterile bench and that conidia are only handled outside the bench if they are in a liquid suspension.

If conducting a bioassay with Aspergillus spp. on in vitro reared larvae or in cages on adult honey bees, it is important that the assessment is done in a sterile bench or a fume hood once the Aspergillus start to sporulate. Dead infected bees can be removed with forceps to avoid production of numerous new conidia.

In several countries, permission from the authorities is required to work experimentally with stonebrood fungi, in particular if it is an outdoor experiment. If Aspergillus spp. are used for experiments in bee colonies we recommend using a mask and safety glasses for protection while conducting the experiments.

\subsection{Diagnostics and qualitative detection}

\subsubsection{Morphological description}

The typical symptoms observed in a colony affected by stonebrood are not very different from chalkbrood symptoms and includes irregular capping of the brood. Infected brood, also called "mummies", can be seen in the combs. Stonebrood mummies turn hard and they resemble small stones, not sponge-like as chalkbrood mummies. Stonebrood mummies are difficult to remove from the cells with forceps and removal by the worker bees is also difficult. Infected brood becomes covered with powdery yellow, brown, green or black fungal spores depending on the species. In some cases infected or deceased larvae looked dry, but they do not produce visible conidia within a 48 hrs after pathogen inoculation (Vojvodic, unpublished)

Stonebrood can be diagnosed by its gross symptoms, but positive identification requires its cultivation in the laboratory and subsequent microscopic examination. Structures of the conidiophores (spore forming structures) are very important for identification of Aspergillus spp. The conidiophores originate from a basal cell located on the supporting hyphae and terminate in a vesicle (Fig. 8). The morphology, colour and roughness of the conidiophores vary from species to species. Additionally, the position of the flask-shaped phialides (spore producing cells) on the vesicle is an important character. The phialides can cover the vesicle surface entirely ("radiate" head) or partially ("columnar" head) and the phialids can be attached to the vesicle directly (uniseriate) or attached via a supporting cell, called metula (biseriate). The phialides produce round conidia (2-5 $\mu \mathrm{m}$ in diameter) 
Table 4. Microscopic characters of three Aspergillus species most often reported to cause stonebrood.

\begin{tabular}{|l|c|c|c|c|}
\hline Species & Conidia colour & Conidiophores & Phialides & Vesicle \\
\hline Asp. flavus & Yellow-green & Colourless. Rough & Uni/biseriate & Round, radiate head \\
\hline Asp. fumigatus & Blue-green to grey & $\begin{array}{c}\text { Short }(<300 \mu \mathrm{m}), \text { smooth, } \\
\text { colourless-green }\end{array}$ & Uniseriate & Round, columnar head \\
\hline Asp. niger & Black & Long, smooth, colourless or brown & Biseriate & Round, radiate head \\
\hline
\end{tabular}

that form radial chains (Fig. 8). The conidia of the different species can have different colours (Table 4) (See Fig. 9 for Asp. flavus in vitro infected larvae). We however recommend contacting a mycologist for correct species identification of the Aspergillus specimens.

\subsubsection{Molecular methods}

There is no single method (morphological, physiological or molecular) that can be used to recognize all of the approximately 250 Aspergillus species. Using a multi-locus approach will give a lot of information, but it also requires certain skills and equipment not always present in diagnostic laboratories (Geiser et al., 2007). A two-step barcoding has been suggested for identification of Aspergillus species in a clinical setting. The ITS regions can be used for inter-section level identification and the $\beta$-tubulin for identification of individual species

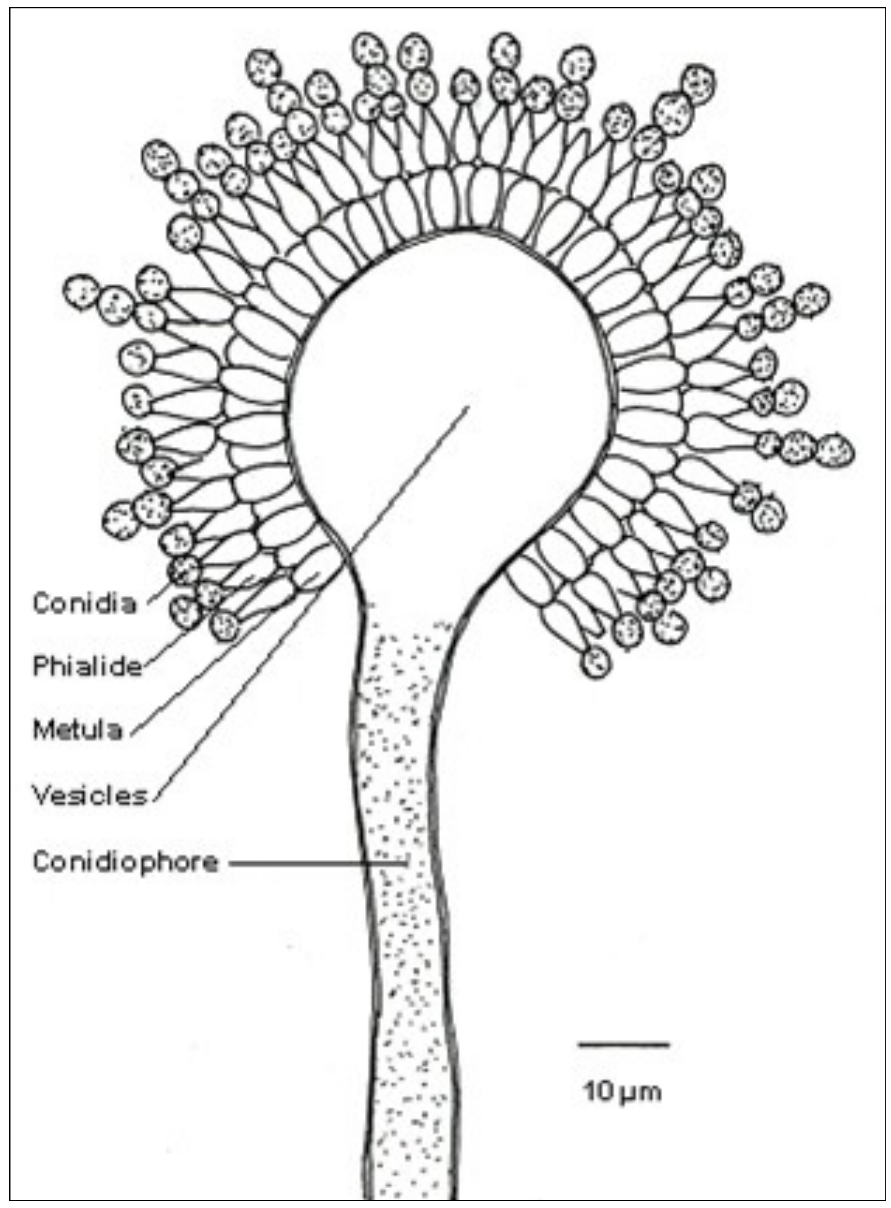

Fig. 8. Structures of importance for identification of Aspergillus species. within the various Aspergillus sections (Balajee et al., 2007)

(see primers in Table 5).

Aspergillus DNA can, as for Ascosphaera, be extracted with standard kits (see also the BEEBOOK paper on molecular methods (Evans et al., 2013)

\subsection{Production and quality of inoculums}

\subsubsection{Isolation techniques}

Aspergillus grows readily on many different standard media e.g. SDA, PDA, but Czapek-Dox medium, which contain sucrose as carbon source and nitrate as the nitrogen source should be very suitable. Czapek-Dox medium with addition of yeast extract $(5.0 \mathrm{~g} / \mathrm{l})$ is recommended (Frisvad, pers. comm.). All these three media can be purchased premixed and easily prepared. E.g. to prepare 1 I of SDA medium, suspend $65 \mathrm{~g}$ SDA (Merck) in 1 I of demineralized water and autoclave $15 \mathrm{~min}$ at $121^{\circ} \mathrm{C}$

\subsubsection{Aspergillus spp. can be isolated from sporulating mummies.}

1. Put a sterile microbial loop in an area with many conidia

2. Streak on agar plates

3. If the plates become contaminated with other microbes, repeat the procedure. Once a clean culture is established, proceed with single spore isolation described below.

\subsubsection{Single spore isolation}

1. Add $10 \mathrm{ml} 0.05 \%$ Triton- $X$ on the culture agar plate

2. Rub its surface gently with a sterile Drigalski spatula to loosen the conidia

3. Transfer the suspension conidia into a $15-50 \mathrm{ml}$ sterile tube

4. Wash the suspension twice (to remove agar and hyphal fragments)

4.1. Centrifuge $3 \mathrm{~min}$ at $7000 \mathrm{~g}$ for $3 \mathrm{~min}$

4.2. Discharge the supernatant and add $10 \mathrm{ml} 0.005 \%$ Triton-X

4.3. Centrifuge $3 \mathrm{~min}$ at $7000 \mathrm{~g}$ for $3 \mathrm{~min}$

4.4. Discharge the supernatant and add $10 \mathrm{ml} 0.005 \%$ Triton-X

5. Prepare a serial dilution (remember to whirl mix before pipetting) 
Table 5. List of primers used to be used in the two-step DNA barcoding of Aspergillus spp. for the ITS region and part of the $\beta$-tubulin gene.

\begin{tabular}{|l|c|c|c|}
\hline Primer name & $\begin{array}{c}\text { Annealing } \\
\text { temp }\left({ }^{\circ} \mathbf{C}\right)\end{array}$ & Annealing temperature $\left.\mathbf{(}^{\circ} \mathbf{C}\right)$ & Citation \\
\hline ITS 1 & 55 & TCCGTAGGTGAACCTGCGG & White et al., 1990 \\
\hline ITS 4 & 55 & TCCTCCGCTTATTGATATGC & White et al., 1990 \\
\hline Bt2a $(\beta$-tubulin) & 58 & GGTAACCAAATCGGTGCTGCTTC & Glass and Donaldson, 1995 \\
\hline Bt2b $(\beta$-tubulin) & 58 & ACCCTCAGTGTAGTGACCCTTGGC & Glass and Donaldson, 1995 \\
\hline
\end{tabular}

6. Count the spore concentration in a haemocytometer (described in the BEEBOOK paper on miscellaneous methods (Human et al., 2013))

7. Transfer $100 \mu \mathrm{l}$ of a spore solution at $5 \times 10^{2}$ spore per $\mathrm{ml}$ to a new plate

8. Incubate at $25^{\circ} \mathrm{C}$ for two-four days

9. Transfer a single small colony to a new plate

To harvest conidia for experimental purposes the above procedure can be used (minus step 6-8). It is important to use Triton-X or another detergent to avoid spore clumping.

\subsubsection{Preservation of in vitro cultures}

Aspergillus has been observed to lose sporulation capacity and virulence after a couple of transfers on a standard medium (Scully and Bidochka, 2006). Therefore we recommend long-term storage of the isolates during the first transfers. Several long-term storage methods can be used: frozen in skim milk, refrigerated with silica gel, or freeze dried. It is possible to successfully recover various Aspergillus species (e.g. Asp. flavus, Asp. parasiticus and Asp. niger), stored in 10\% glycerol at $-80^{\circ} \mathrm{C}$ for more than a year, using the same method which we recommend for $A$. apis (see paragraph 1.4.3.1. Cryopreservation in glycerol at $-80^{\circ} \mathrm{C}$ ).

\subsection{Quality test of inoculums}

Viability testing of Aspergillus spp. can be performed using the standard insect pathology methods, which are briefly described below.

\subsubsection{Spore viability and germination test}

1. Transfer $10 \mu \mathrm{l}$ of a spore solution at $5 \times 10^{5}$ spore per $\mathrm{ml}$ to an agar plate

2. Spread the spore solution over the entire ager plate with a sterile Digralski spatula

3. Incubate at $25^{\circ} \mathrm{C}$ for 24 hour

4. Place three cover slips on the plate

5. Place the agar plate under the microscope and count the proportion of germinated spores out of 100 spores under each of the three cover slips

It is recommended to use only new fresh spore solution for each experiment because the shelf life of Aspergillus spores in a water solution is about 3 days (Vojvodic, unpublished).

\subsubsection{Availability and recommended reference isolates}

Aspergillus has been deposited in various fungal culture collections, such as USDA-ARSEF, ATCC and CBS (see link below). None of the isolates deposited so far have been isolated from honey bees, neither larvae nor adults, but from sources such as plant material, soil, vertebrates and invertebrates. USDA-ARSEF is a collection of Entomopathogenic fungi, thus the majority of isolated deposited there originate from insects or other arthropods. It is possible to retrieve Aspergillus isolates from hymenoptera; solitary megachilid bees (Osmia lignaria and Megachile rotundata) and formicine ants (Anoplolepsis longipes and Solenopsis invicta).

Limited work has been performed with stonebrood, thus it is difficult to recommend a specific reference strain. A reference strain can be chosen based on its pathobiological properties (to honey bees or at least Hymenoptera); as in Vojvodic et al. (2011a) where an Asp. flavus strain isolated from an infected honey bee larvae was used to infect in vitro reared honey bee larvae. This particular strain is unfortunately lost. However, the reference strain could be based on its geographical origin or type specimen.

USDA-ARSEF; ARS Collection of Entomopathogenic Fungi (83 isolates deposited, 15 Asp. flavus, 7 Asp. niger April 2012)

http://www.ars.usda.gov/Main/docs.htm?docid=12125

ATCC; American Type Culture Collection (1618 isolates deposited, 180 Asp. favus, 111 Asp. fumingatus, 117 Asp. niger, April 2012)

http://www.lgcstandards-atcc.org/

CBS; Centraalbureau voor Schimmelcultures (1055 isolates deposited, 47 Asp. flavus, 147 Asp. fumigatus, 7 Asp. niger, April 2012) http://www.cbs.knaw.nl/

Aspergillus is classified as an opportunistic human pathogen, and thus some countries will need an import permit and proof that the laboratory is accredited to handle it.

\subsection{Infection bioassays}

Exposure bioassays with Aspergillus spp. can potentially be carried out, using in vitro reared larvae (Fig. 9), caged bees or colonies, due to its ability to infect larvae, pupae and adults. A bioassay with in vitro reared larvae has been conducted showing that stonebrood and chalkbrood had opposite temperature-dependent responses in virulence. Chilling of chalkbrood exposed larvae increased the 


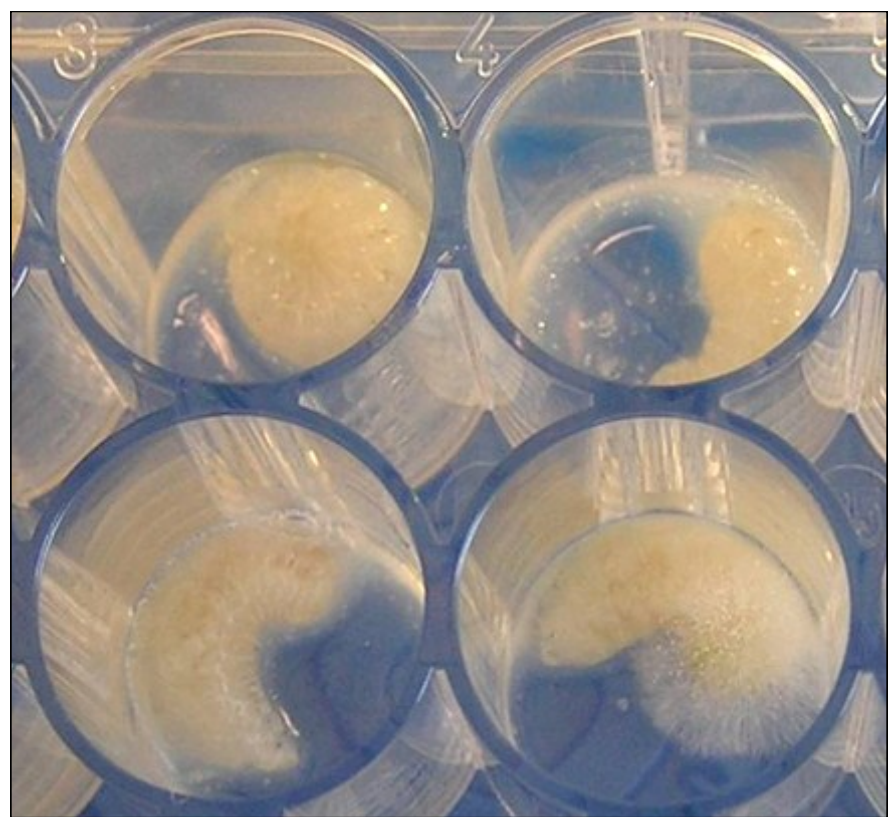

Fig. 9. In vitro reared honey bee larvae infected with Aspergillus flavus the bottom left cell contains larvae in an early stage of disease visible by the change in larval colour; bottom right cell contains later stage of the diseases with the visible fungal body and conidia protruding out of the larval cuticle. The two upper cells contain healthy larvae.

Photo: S Vojvodic

pathogen virulence; whereas chilling of stonebrood exposed larvae increased larval survival (Vojvodic et al., 2011a). For infection of in vitro bee larvae with Aspergillus spp. the same precautions must be taken as described in paragraph 1.5.1. for $A$. apis.

Few experiments with caged bees have been conducted (Gilliam and Vandenberg, 1997). Infecting individual larvae while still in the brood frame is possible by placing the spore suspensions to be ingested in front of the larvae (Vojvodic unpublished).

\section{Future perspectives}

Chalkbrood and stonebrood diseases have been recognized for more than a century, but there is still much that remains to be discovered regarding these diseases and their impact on the general health status of honey bees. The numbers of studies of the two diseases reflects their frequency and abundance, with a magnitude difference in favour of chalkbrood.

The genome of $A$. apis was published in 2006 (Qin et al., 2006), and although the full annotation is still lacking, it will be useful for future research investigations on the expression of genes important for the infection and virulence of $A$. apis. Chalkbrood is a stress related disease and a recent longitudinal cohort study based on monitoring data collected over six years indicated that colonies with high numbers of varroa mites in the same season or Nosema ceranae infection in the spring had significantly higher chances of chalkbrood outbreaks (Hedtke et al., 2011). Such a correlation needs experimental confirmation, but it elucidates the complexity of the host-pathogeninteraction in honey bee colonies. Research on the interaction with other pathogens and stressors, such as sublethal concentration of various chemicals, is also warranted.

Aspergillus research is mostly focused on human health and food spoilage due to aflatoxin contamination of grains. Stonebrood outbreaks are rarely observed in honey bee colonies, but should not be underestimated. Their rarity could be a result of honey bees removing the stonebrood infected individuals very quickly, an area of research that has not been previously investigated. Furthermore, the basic biology of stonebrood is still poorly understood, and several studies elucidating stonebrood etiology are still to be performed. Aspergillus spp. spores are present everywhere and a high virulence towards honey bee larvae have been shown. Even though stonebrood is rarely reported, it would be interesting to understand which factors and mechanisms might play a role in the establishment and resistance of this disease.

\section{References}

ANDERSON, D L; GIBSON, N L (1998) New species and isolates of spore-cyst fungi (Plectomycetes: Ascosphaerales) from Australia. Australian Systematic Botany 11: 53-72. http://dx.doi.org/10.1071/SB96026

ANDERSON, D L; GIBBS, A J; GIBSON, N L (1998) Identification and phylogeny of sporecyst fungi (Ascosphaera spp ) using ribosomal DNA sequences. Mycological Research 102: 541-547. http://dx.doi.org/10.1017/S0953756297005261

ARONSTEIN, K A; MURRAY, K D; DE LEON, J; QIN, X; WEINSTOCK, G (2007) High mobility group (HMG-box) genes in the honey bee fungal pathogen Ascosphaera apis. Mycologia 99: 553-561. http://dx.doi.org/10.3852/mycologia.99.4.553

ARONSTEIN, K A; MURRAY, K D (2010) Chalkbrood disease in honey bees. Journal of Invertebrate Pathology 103: 20-29. http://dx.doi.org/10.1016/j.jip.2009.06.018

ARONSTEIN, K A; MURRAY, K D; SALDIVAR, E (2010) Transcriptional responses in Honey bee larvae infected with chalkbrood fungus. $B M C$ Genomics 11: 391. http://dx.doi.org/10.1186/1471-2164-11-391

BAILEY, L (1981) Honey bee pathology. Academic Press; London, UK. pp. 40-44.

BAMFORD, S; HEATH, L A F (1989) The effects of temperature and $\mathrm{pH}$ on the germination of spores of the chalkbrood fungus, Ascosphaera apis. Journal of Apicultural Research 28: 36-40.

BALAJEE, S A; HOUBRAKEN, J; VERWEIJ, P E; HONG, S-B; YAGUCHI, T; VARGA, J; SAMSON, R A (2007). Aspergillus species identification in the clinical setting. Studies in Mycology 59: 39-46. http://dx.doi.org/10.3114/sim.2007.59.05 
BETTS, A D (1951) The diseases of bees: their signs, causes and treatment. Hickmott: Camberley, UK.

BISSETT, J (1988) Contribution toward a monograph of the genus Ascosphaera. Canadian Journal of Botany 66: 2541-2560.

BURNSIDE, C E (1930) Fungous diseases of the honey bee. US Department of Agriculture Technical Bulletin 149.

BÜCHLER, R; ANDONOV, S; BIENEFELD, K; COSTA, C; HATJINA, F; KEZIC, N; KRYGER, P; SPIVAK, M; UZUNOV, A; WILDE, J (2013) Standard methods for rearing and selection of Apis mellifera queens. In V Dietemann; J D Ellis; P Neumann (Eds) The COLOSS BEEBOOK, Volume I: standard methods for Apis mellifera research. Journal of Apicultural Research 52(1):

http://dx.doi.org/10.3896/IBRA.1.52.1.07

CRAILSHEIM, K; BRODSCHNEIDER, R; AUPINEL, P; BEHRENS, D; GENERSCH, E; VOLLMANN, J; RIESSBERGER-GALLÉ, U (2013) Standard methods for artificial rearing of Apis mellifera larvae. In V Dietemann; J D Ellis; P Neumann (Eds) The COLOSS BEEBOOK, Volume I: standard methods for Apis mellifera research. Journal of Apicultural Research 52(1):

http://dx.doi.org/10.3896/IBRA.1.52.1.05

DE MIRANDA, J R; BAILEY, L; BALL, B V; BLANCHARD, P; BUDGE, G; CHEJANOVSKY, N; CHEN, Y-P; VAN DOOREMALEN, C; GAUTHIER, L; GENERSCH, E; DE GRAAF, D; KRAMER, M; RIBIÈRE, M; RYABOV, E; DE SMET, L VAN DER STEEN, J J M (2013) Standard methods for virus research in Apis mellifera. In V Dietemann; $J D$ Ellis; P Neumann (Eds) The COLOSS BEEBOOK, Volume II: standard methods for Apis mellifera pest and pathogen research. Journal of Apicultural Research 52(4):

http://dx.doi.org/10.3896/IBRA.1.52.4.22

DENNING, D W (1998) Invasive aspergillosis. Clinical Infectious Diseases 26: 781-803. http://dx.doi.org/10.1086/513943

EVANS, J D; CHEN, Y P; CORNMAN, R S; DE LA RUA, P; FORET, S; FOSTER, L; GENERSCH, E; GISDER, S; JAROSCH, A; KUCHARSKI, R; LOPEZ, D; LUN, C M; MORITZ, R F A; MALESZKA, R; MUÑOZ, I; PINTO, M A; SCHWARZ, R S (2013) Standard methodologies for molecular research in Apis mellifera. In $V$ Dietemann; $J$ D Ellis; $P$ Neumann (Eds) The COLOSS BEEBOOK, Volume I: standard methods for Apis mellifera research. Journal of Apicultural Research 52(4): http://dx.doi.org/10.3896/IBRA.1.52.4.11

FLORES, J M; RUIZ, J A; RUZ, J M; PUERTA, F; BUSTOS, M; PADILLA, F; CAMPANO, $F$ (1996a) Effect of temperature and humidity of sealed brood on chalkbrood development under controlled conditions. Apidologie 27: 185-192. http://dx.doi.org/10.1051/apido:19960401

FLORES, J M; RUÍZ, J A; RUZ, J M; PUERTA, F; BUSTOS, M; PADILLA, $\mathrm{F}$; CAMPANO, $\mathrm{F}$ (1996b) Estudio in vivo e in vitro para el control de la ascosferiosis en apis mellifera. Revista Iberoamericana de Micología 13: 292-295.
FLORES, J M; PUERTA, F; GUTIÉRREZ, I; ARREBOLA, F (2001) Estudio de la eficacia del Apimicos-b ${ }^{\circledR}$ en el control y la prevención de la ascosferiosis en la abeja de la miel. Revista Iberoamericana de Micología 18: 187-190.

FLORES, J M; GUTIÉRREZ, I; PUERTA, F (2004a) A comparison of methods to experimentally induce chalkbrood disease in honey bees. Spanish Journal of Agricultural Research 2: 79-83.

FLORES, J M; GUTIÉRREZ, I; PUERTA, F (2004b) Oxytetracycline as a predisposing condition for chalkbrood in honey bee. Veterinary Microbiology 103: 195-199.

http://dx.doi.org/10.1016/j.vetmic.2004.07.012

FLORES, J M; SPIVAK, M; GUTIÉRREZ, I (2005a) Spores of Ascosphaera apis contained in wax foundation can infect honey bee brood. Veterinary Microbiology 108: 141-144. http://dx.doi.org/10.1016/j.vetmic.2005.03.005 FORSGREN, E; BUDGE, G E; CHARRIÈRE, J-D; HORNITZKY, M A Z (2013) Standard methods for European foulbrood research. In $V$ Dietemann; J D Ellis, P Neumann (Eds) The COLOSS BEEBOOK: Volume II: Standard methods for Apis mellifera pest and pathogen research. Journal of Apicultural Research 52(1):

http://dx.doi.org/10.3896/IBRA.1.52.1.12

FRIES, I; CHAUZAT, M-P; CHEN, Y-P; DOUBLET, V; GENERSCH, E; GISDER, S; HIGES, M; MCMAHON, D P; MARTÍN-HERNÁNDEZ, R; NATSOPOULOU, M; PAXTON, R J; TANNER, G; WEBSTER, T C; WILLIAMS, G R (2013) Standard methods for nosema research. In $\checkmark$ Dietemann; J D Ellis, P Neumann (Eds) The COLOSS BEEBOOK: Volume II: Standard methods for Apis mellifera pest and pathogen research. Journal of Apicultural Research 52(1): http://dx.doi.org/10.3896/IBRA.1.52.1.14

GALIMBERTI, R; KOWALCZUK, A; PARRA, I H; RAMOS M G; FLORES, V (1998) Cutaneous aspergillosis: a report of six cases. British Journal of Dermatology 139: 522-526.

http://dx.doi.org/10.1046/j.1365-2133.1998.02424.x

GARRETT, D O; JOCHIMSEN, E; JARVIS, W (1999) Invasive Aspergillus spp. infections in rheumatology patients. Journal of Rheumatology 26: 146-149.

GEFTER, W B (1992) The spectrum of pulmonary aspergillosis. Journal of Thoracic Imaging 7: 56-74.

GERMAUD, P; TUCHAIS, E (1995) Allergic bronchopulmonary aspergillosis treated with itraconazole. Chest 107: 883. http://dx.doi.org/10.1378/chest.107.3.883

GEISER, D M; KLICH, M A; FRISVAD, J C; PETERSON, S W; VARGA, J; SAMSON, R A (2007) The current status of species recognition and identification in Aspergillus. Studies in Mycology 59: 1-10. http://dx.doi.org/10.3114/sim.2007.59.01

GILLIAM, M; TABER, S; RICHARDSON, G V (1983) Hygienic behaviour of honey bees in relation to chalkbrood disease. Apidologie 14: 29-39. http://dx.doi.org/10.1051/apido:19830103 
GILLIAM, M; VANDENBERG, J (1997) Fungi. In Morse, $R$ A; Flottum, $K$ JAMES, R R; SKINNER, J S (2005) PCR diagnostic methods for

(Eds). Honey bee pests, predators, \& diseases (3rd Edition). A I

Root Co.; Medina, USA. pp. 81-110.

GLASS, N L; DONALDSON, G C (1995) Development of primer sets designed for use with the PCR to amplify conserved genes from filamentous ascomycetes. Applied and Environmental Microbiology 61: 1323-1330.

GOCHNAUER, T A; FURGALA, B; SHIMANUKI, H (1975) Diseases and enemies of the honey bee. In Grout $R$ (Ed.) The hive and the honey bee (3rd Ed.). Dadant and Sons; Hamilton, USA. pp. 615-621. GRAMACHO, K P; SPIVAK, M (2003) Differences in olfactory sensitivity and behavioural responses among honey bees bred for hygienic behaviour. Behavioural Ecology and Sociobiology 54: 472-479. http://dx.doi.org/10.1007/s00265-003-0643-y

HEATH, L A F (1982) Development of chalkbrood in a honey bee colony: a review. Bee World 63: 119-130.

HEATH, L A F; GAZE, B M (1987) Carbon dioxide activation of spores of the chalkbrood fungus Ascosphaera apis. Journal of Apicultural Research 26(4): 243-246.

HEDTKE, K; JENSEN, P M; JENSEN, A B; GENERSCH, E (2011) Evidence for emerging parasites and pathogens influencing outbreaks of stress-related diseases like chalkbrood. Journal of Invertebrate Pathology 108:167-73. http://dx.doi.org/10.1016/j.jip.2011.08.006

HORNITZKY, M (2001) Literature review of chalkbrood. A report for the RIRDC. Publication No. 01/150, Kingston, ACT, Australia. HUMAN, H; BRODSCHNEIDER, R; DIETEMANN, V; DIVELY, G; ELLIS, J; FORSGREN, E; FRIES, I; HATJINA, F; HU, F-L; JAFFÉ, R; KÖHLER, A; PIRK, C W W; ROSE, R; STRAUSS, U; TANNER, G; TARPY, D R; VAN DER STEEN, J J M; VEJSN/ES, F; WILLIAMS, G R; ZHENG, H-Q (2013) Miscellaneous standard methods for Apis mellifera research. In V Dietemann; $J$ D Ellis; P Neumann (Eds) The COLOSS BEEBOOK, Volume I: standard methods for Apis mellifera research. Journal of Apicultural Research 52(4): http://dx.doi.org/10.3896/IBRA.1.52.4.10

HUMBER, R A (2008) Evolution of entomopathogenicity in fungi. Journal of Invertebrate Pathology 98: 262-266. http://dx.doi.org/10.1016/j.jip.2008.02.017

INVERNIZZI, C; PENAGARICANO, F; TOMASCO, I H (2009) Intracolonial genetic variability in honey bee larval resistance to the chalkbrood and American foulbrood parasites. Insectes Sociaux 56: 233-240. http://dx.doi.org/10.1007/s00040-009-0016-2
Ascosphaera infections in bees. Journal of Invertebrate Pathology 90: 98-103. http://dx.doi.org/10.1016/j.jip.2005.08.004

JAMES, T Y; KAUFF, F; SCHOCH, C; MATHENY, P B; HOFSTETTER, V; COX, C J; CELIO, G; GEUIDAN, C; FRAKER, E; MIADLIKOWSKA, J; LUMBSCH, H T; RAUHUT, A; REEB, V; ARNOLD, A E; AMROFT, A; STAJICH, J E; HOSAKA, K; SUNG, G -H; JOHNSON, D; O'ROURKE, B; CROCKETT, M; BINDER, M; CURTIS, J M; SLOT, J C; WANG, Z; WILSON, A W; SCHÜßLER, A; LONGCORE, J E; O'DONNELL, K; MOZLEY-STANDRIDGE, S; . ORTER, D; LETCHER, P M; POWELL, M J; TAYLOR, J W; WHITE, M M; GRIFFITH, G W; DAVIES, D R; HUMBER, R A; MORTON, J B; SUGIYAMA, J; ROSSMAN, A; ROGERS, J D; PFISTER, D H; HEWITT, D; HANSEN, K; HAMBLETON, S; SHOEMAKER, R A; KOHLMEYER, J; VOLKMANNKOHLMEYER, B; SPOTTS, R A; SERDANI, M; CROUS, P W; HUGHES, K W; MATSUURA, K; LANGER, E; LANGER, G; UNTEREINER, W A; LÜCKING, R; BÜDEL, B; GEISER, D M; APTROOT, A; DIEDERICH, P; SCHMITT, I; SCHULTZ, M; YAHR, R; HIBBETT, D S; LUTZONI, F; MCLAUGHLIN, D J; SPATAFORA, J W; VILGALYS, R (2006) Reconstructing the early evolution of Fungi using a six-gene phylogeny. Nature 443: 818-822. http://dx.doi.org/10.1038/nature05110

JENSEN, A B; JAMES, R R; EILENBERG, J (2009a) Long-term storage of Ascosphaera aggregata and A. apis, pathogens of the leafcutting bee (Megachile rotundata) and the honey bee (Apis mellifera). Journal of Invertebrate Pathology 101: 157-160. http://dx.doi.org/10.1016/j.jip.2009.03.004

JENSEN, A B; PEDERSEN, B V; EILENBERG, J (2009b) Differential susceptibility across honey bee colonies in larval to chalkbrood resistance. Apidologie 40: 524-534. http://dx.doi.org/10.1051/apido/2009029

JENSEN, A B; WELKER, D L; KRYGER, P; JAMES, R R (2012) Polymorphic DNA sequences of the fungal honey bee pathogen Ascosphaera apis. FEMS Microbiology Letters 330: 17-22. http://dx.doi.org/10.1111/j.1574-6968.2012.02515.x

LUNDER, R (1972) Undersøkelse av kalkyngel i 1971 [Investigation on chalkbrood in 1971]; Birøkteren 88: 55-60.

MAASSEN, A (1913) Weitere Mitteilungen uber der seuchenhaften Brutkrankheiten der Bienen [Further communication on the epidemic brood disease of bees]. Mitteilungen aus der Kaiserlichen Biologischen Anstalt fur Land- und Forstwirtscshaft 14: 48-58. 
MASTERMAN, R; SMITH, B H; SPIVAK M (2000) Brood odour discrimination abilities in hygienic honey bees (Apis mellifera $\mathrm{L}$ ) using proboscis extension reflex conditioning. Journal of Insect Behaviour 13(1): 87-101. http://dx.doi.org/10.1023/A:1007767626594

MASTERMAN, R; ROSS, R; MESCE, K; SPIVAK, M (2001) Olfactory and behavioural response thresholds to odours of diseased brood differ between hygienic and non-hygienic honey bees (Apis mellifera L.). Journal of Comparable Physiology A 187:441-452. http://dx.doi.org/10.1007/s003590100216

MAURIZIO, A (1934) Uber die Kaltbrut (Pericystis-Mykose) der Bienen. Archiv Bienenkunde 15: 165-193.

MOFFETT, J O; WILSON, W T (1978) Feeding commercially purchased pollen containing mummies caused chalkbrood. American Bee Journal 118: 412-414.

MOMOT, J P; ROTHENBUHLER, W C (1971) Behaviour genetics of nest cleaning in honey bees. VI. Interactions of age and genotype of bees, and nectar flow. Journal of Apicultural Research 10: 11-21. MURRAY, K D; ARONSTEIN, K A; JONES, W A (2005) A molecular diagnostic method for selected Ascosphaera species using PCR amplification of internal transcribed spacer regions of rDNA. Journal of Apicultural Research 44: 61-64.

NILSSON, H; KRISTIANSSON, E; RYBERG, M; HALLENBERG, N; LARSSON, K H (2008) Intraspecific ITS variability in the kingdom Fungi as expressed in the International Sequence Databases and its implications for molecular species identification. Evolutionary Bioinformatics Online 4: 193-201.

PALACIO, M A; FIGINI, E; RODRIGUEZ, E; RUFFINENGO, S; BEDASCARRASBURE, E; DELHOYO, M (2000) Changes in a population of Apis mellifera selected for its hygienic behaviour. Apidologie 31:471-478. http://dx.doi.org/10.1051/apido:2000139

PALACIO, M A; PEÑA, N; CLEMENTE, G; RUFFINENGO, S; ESCANDE, A (2007) Viability and pathogenicity of Ascosphaera apis preserved in integral rice culture. Journal of Agricultural Research 5(4): 481486.

PALACIO, M A; RODRIGUEZ, E; GONCALVES, L; BEDASCARRASBURE, E; SPIVAK, M (2010) Hygienic behaviours of honey bees in response to brood experimentally pin-killed or infected with Ascosphaera apis. Apidologie 41: 602-612. http://dx.doi.org/10.1051/apido/2010022

PUERTA, F; FLORES, J M; TARÍN, R; BUSTOS, M; PADILLA, F, HERMOSO DE MENDOZA, M (1990) Actividad antifúngica de productos seleccionados contra Ascosphaera Apis. Estudios in vitro. Revista Iberoamericana de Micología 7: 103-106.

QIN, X; EVANS, J D; ARONSTEIN, K A; MURRAY, K D; WEINSTOCK, G $M(2006)$ Genome sequences of the honey bee pathogens Paenibacillus larvae and Ascosphaera apis. Insect Molecular Biology 15(5): 715-718.

http://dx.doi.org/10.1111/j.1365-2583.2006.00694.x
REHNER, S A; EVANS, J D (2009) Microsatellite loci for the fungus Ascosphaera apis. cause of honey bee chalkbrood disease. Molecular Ecology Resources 9: 855-858.

REYNALDI, F J; LOPEZ, A C; ALBO. G N; ALIPPI, A M (2003) Differentiation of Ascosphaera apis isolates by rep-PCR fingerprinting and determination of chalkbrood incidence in Argentinean honey samples. Journal of Apicultural Research 42: $68-76$.

ROTHENBUHLER, W C (1964) Behaviour genetics of nest cleaning in honey bees. IV. Responses of F1 and backcross generations to disease-killed brood. American Zoologist 4(2): 111-123. http://dx.doi.org/10.1016/0003-3472(64)90082-X

RUFFINENGO, S; PEÑA, N I; CLEMENTE, G; PALACIO, M A; ESCANDE, $R$ (2000) Suitability of culture media for the production of ascospores and maintenance of Ascosphaera apis. Journal of Apicultural Research 39(3/4): 143-148.

SCHEINER, R; ABRAMSON, C I; BRODSCHNEIDER, R; CRAILSHEIM, K; FARINA, W; FUCHS, S; GRÜNEWALD, B; HAHSHOLD, S; KARRER, M; KOENIGER, G; KOENIGER, N; MENZEL, R; MUJAGIC, S; RADSPIELER, G; SCHMICKLI, T; SCHNEIDER, C; SIEGEL, A J; SZOPEK, M; THENIUS, R (2013) Standard methods for behavioural studies of Apis mellifera. In V Dietemann; J D Ellis; $P$ Neumann (Eds) The COLOSS BEEBOOK, Volume I: standard methods for Apis mellifera research. Journal of Apicultural Research 52(4): http://dx.doi.org/10.3896/IBRA.1.52.4.04

SCHOCH, C L; SEIFERT, K A; HUHNDORFC, S; ROBERT, V; SPOUGE, J L; LEVESQUEB, C A; CHEN, W; (FUNGAL BARCODING CONSORTIUM) (2012) Nuclear ribosomal internal transcribed spacer (ITS) region as a universal DNA barcode marker for Fungi. Proceedings of the National Academy of Sciences 109: 6241-6246. www.pnas.org/cgi/doi/10.1073/pnas.1117018109

SCULLY, L R; BIDOCHKA, M J (2006) A cysteine/methionine auxotroph of the opportunistic fungus Aspergillus flavus is associated with host-range restriction: a model for emerging diseases. Microbiology 152: 223-232. http://dx.doi.org/10.1099/mic.0.28452-0

SEAL, D W A (1957) Chalk brood disease of bees. New Zealand Journal of Agriculture 6: 562.

SKOU, J P (1972) Ascosphaerales. Friesia 10(1): 1-24.

SKOU, J P (1988) More details in support of the class Ascosphaeromycetes. Mycotaxon 31(1): 191-198.

SPILTOIR, C F (1955) Life cycle of Ascosphaera apis (Pericystis apis). American Journal of Botany 42(6): 501-508. http://dx.doi.org/10.2307/2438686

SPIVAK, M; GILLIAM, M (1993) Facultative expression of hygienic behaviour of honey bees in relation to disease resistance. Journal of Apicultural Research 32: 147-157.

SPIVAK, M; REUTER, G S (2001) Resistance to American foulbrood disease by honey bee colonies, Apis mellifera, bred for hygienic behaviour. Apidologie 32: 555-565. http://dx.doi.org/10.1051/apido:2001103 
SPIVAK, M; MASTERMAN, R; ROSS, R; MESCE, K A (2003) Hygienic behaviour in the honey bee (Apis mellifera L.) and the modulatory role of octopamine. Journal of Neurobiology 55: 341-354. http://dx.doi.org/10.1002/neu.10219

SWANSON, J; TORTO, B; KELLS, S; MESCE, K; TUMLINSON, J; SPIVAK, M (2009) Odorants that induce hygienic behaviour in honey bees: Identification of volatile compounds in chalkbroodinfected honey bee larvae. Journal of Chemical Ecology 35: 11081116. http://dx.doi.org/10.1007/s10886-009-9683-8

TABER, S (1986) Breeding bees for resistance to chalkbrood disease. American Bee Journal 126: 823-825.

THOMPSON, V C (1964) Behaviour genetics of nest cleaning in honey bees. III. Effect of age of bees of a resistant line on their response to disease-killed brood. Journal of Apicultural Research 3: 25-30. TORTO, B; CARROLL, M J; DUEHL, A; FOMBONG, A T; NAZZI, F., GOZANSKY, K T; SOROKER, V; TEAL, P E A (2013) Standard methods for chemical ecology research in Apis mellifera. In $V$ Dietemann; J D Ellis; P Neumann (Eds) The COLOSS BEEBOOK, Volume I: standard methods for Apis mellifera research. Journal of Apicultural Research 52(4): http://dx.doi.org/10.3896/IBRA.1.52.4.06

TOUMANOFF, C; (1951) Les Maladies des Abeilles [The diseases of bees]. Revue Française d'Apicculture numéro spécial 68: 1-325.
UDAGAWA, S; HORIE, Y (1976) A new species of Emericella. Mycotaxon 4: 535-539.

VOJVODIC, S; BOOMSMA, J J; EILENBERG, J; JENSEN, A B (2012) Virulence of mixed fungal infections in honey bee brood. Frontiers in Zoology 9:5. http://dx.doi.org/10.1186/1742-9994-9-5 VOJVODIC, S; JENSEN, A B; JAMES, R R; BOOMSMA, J J; EILENBERG, J (2011a). Temperature dependent virulence of obligate and facultative fungal pathogens of honey bee brood. Veterinary Microbiology 149: 200-205.

http://dx.doi.org/10.1016j.vetmic.2010.10.001

VOJVODIC, S; JENSEN, A B; MARKUSSEN, B; EILENBERG, J; BOOMSMA, J J (2011b) Genetic variation in virulence among chalkbrood strains infecting honey bees. PLOS ONE 6(9): e25035. http://dx.doi.org/10.1371/journal.pone.0025035

WHITE, T; BURNS, T; LEE, S; TAYLOR, J (1990) Amplification and direct sequencing of fungal ribosomal RNA genes for phylogenetics. In Innis, M A; Gelfand, D H; Sninsky, J J; White, $T$ $J$ (Eds). PCR protocols. A guide to methods and applications. Academic Press, Inc.; Sand Diego, USA. pp. 315-322. WILSON-RICH, N; SPIVAK, M; FEFFERMAN, N H; STARKS, P T (2009) Genetic, individual, and group facilitation of disease resistance in insect societies. Annual Review of Entomology 54: 405-423. http://dx.doi.org/10.1146/annurev.ento.53.103106.093301 